\title{
Convective activities associated with intraseasonal variation over Sumatera, Indonesia, observed with the equatorial atmosphere radar
}

\author{
T. H. Seto, M. K. Yamamoto, H. Hashiguchi, and S. Fukao \\ Research Institute for Sustainable Humanosphere, Kyoto University, Uji, Kyoto 611-0011, Japan \\ Received: 23 October 2003 - Revised: 14 June 2004 - Accepted: 24 June 2004 - Published: 29 November 2004 \\ Part of Special Issue "10th International Workshop on Technical and Scientific Aspects of MST Radar (MST10)"
}

\begin{abstract}
The influence of intraseasonal variation (ISV) on convective activities over Sumatera (or Sumatra) is studied by using data derived from the Equatorial Atmosphere Radar (EAR), the Boundary Layer Radar (BLR), the surface weather station, the Geostationary Meteorological Satellite (GMS), and NCEP/NCAR reanalysis. In June 2002, convective activities over the Indian Ocean, the maritime continent, and the western Pacific were significantly modulated by the ISV. Blackbody brightness temperature observed by GMS ( $\mathrm{T}_{\mathrm{BB}}$ ) showed that two super cloud clusters (SCCs) developed over the Indian Ocean $\left(70-90^{\circ} \mathrm{E}\right)$ in the first half of June 2002, and propagated eastward from the Indian Ocean to the western Pacific. Convective activities were enhanced over the western Pacific $\left(130-160^{\circ} \mathrm{E}\right)$ in the latter half of June 2002. Convergence at $1000 \mathrm{hPa}$, which prevailed over the Indian Ocean in the first half of June 2002, propagated eastward to the western Pacific in the latter half of June 2002. Zonal wind observed by EAR and surface pressure observed at the observation site suggested the existence of a Kelvin-wave-like structure of ISV. From temporal variations of $\mathrm{T}_{\mathrm{BB}}$, zonal wind at $850 \mathrm{hPa}$, and vertical shear of horizontal wind between 700 and $150 \mathrm{hPa}$, we classified the observation periods into the inactive phase (1-9 June), active phase (10-19 June), and postwesterly wind burst phase of ISV (20-26 June). During the inactive phase of ISV, convective activities caused by local circulation were prominent over Sumatera. Results of radar observations indicated the dominance of convective rainfall events over the mountainous area of Sumatera during the inactive phase of ISV. During the active phase of the ISV, cloud clusters (CCs), which developed in the convective envelope of SCC with a period of 1-2 days, mainly induced the formation of convective activities over Sumatera. Results of radar observations indicated that both convective and stratiform rainfall events occurred over the mountainous area of Sumatera during the active phase of ISV. In the postwesterly wind burst phase of ISV,
\end{abstract}

Correspondence to: M. K. Yamamoto

(m-yamamo@ rish.kyoto-u.ac.jp) convective activities were suppressed over Sumatera. Features of convective activities found over Sumatera generally agreed well with those found in Tropical Ocean and Global Atmosphere/Coupled Ocean-Atmosphere Response Experiment (TOGA COARE). However, local circulation played an important role in the formation of convective activities over Sumatera in the inactive phase of ISV.

Key words. Meteorology and atmospheric dynamics (convective processes; precipitation; tropical meteorology)

\section{Introduction}

IntraSeasonal Variation (ISV) is a dominant mode of convective anomalies in the tropics. It is characterized by eastwardpropagating convection and circulation anomalies with a period between 30 and 60 days in the tropics (e.g. Matthews, 2000; Madden and Julian, 1994; Hendon and Salby, 1994; Rui and Wang, 1990). A hierarchy of convective system exists within ISV. The large-scale envelope of convection is characterized as an eastward propagating disturbance which predominantly has a zonal wave number of 2 and is confined over the Indian Ocean and western Pacific. Synoptic and mesoscale convective activities are enhanced within the wet phase of the large-scale envelope (Hendon and Liebmann, 1994). Nakazawa (1988) showed that eastward-propagating cloud systems within the large-scale envelope of ISV are composed of several eastward-propagating cloud clusters (SCCs). Each SCC has a scale on the order of $1000 \mathrm{~km}$, and consists of smaller cloud clusters (CCs) that propagate westward. Each CC has a scale on the order of $100 \mathrm{~km}$, and a lifetime of 1-2 days.

Sumatera is located at the eastern edge of the Indian Ocean (see Fig. 1). In the west side of Sumatera, there are many high mountains with a height of $>1000 \mathrm{~m}$ (see also Fig. 16 of Nitta et al., 1992). Many studies suggested that Sumatera plays an important role on the eastward propagation of ISV. Weickmann and Khalsa (1990) showed that 


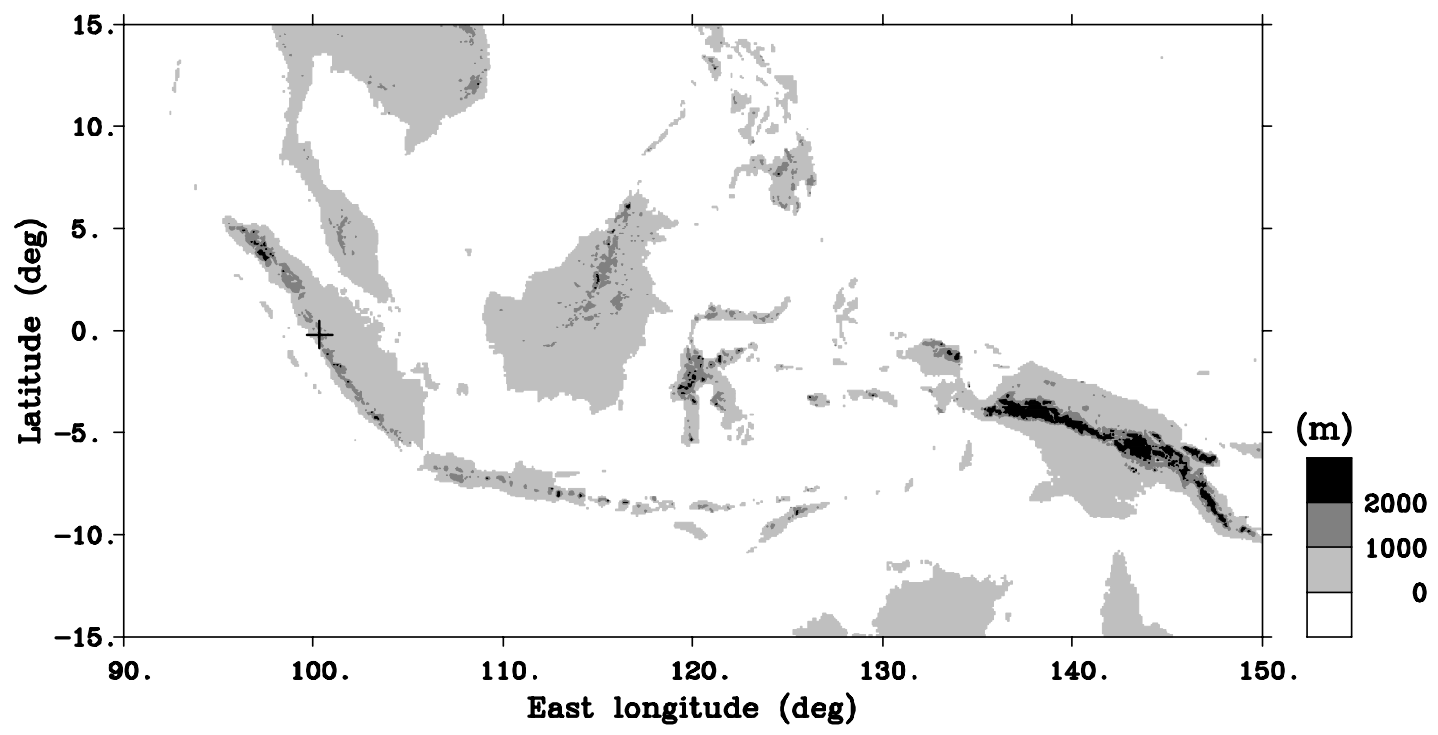

Fig. 1. Geographical map of the Indonesian maritime continent. "+” indicates the location of the observation site $\left(0.20^{\circ} \mathrm{S}, 100.32^{\circ} \mathrm{E}, 865 \mathrm{~m}\right.$ above sea level).

eastward-propagating SCCs are accompanied by local flareups of a convective event near Sumatera $\left(\sim 100^{\circ} \mathrm{E}\right)$. On the other hand, ISV is temporarily depressed over the maritime continent (e.g. Dunkerton and Crum, 1995; Nitta et al., 1992). Nitta et al. (1992) showed that eastward propagations of SCCs are blocked by the surface topography over the maritime continent (especially over Sumatera) when they reach over it. In some cases, no new system can develop in the western Pacific after the convective systems are damped over the maritime continent. However, in some other cases a new SCC is generated to the east of Borneo (see Fig. 19 of Nitta et al., 1992).

Diurnal variation is also one of the dominant modes of convective activities in the tropics. From the satellite observation of brightness temperature, Hendon and Woodberry (1993) showed that diurnal variations of tropical convective activity appear in all seasons, and the intensity of diurnal variations of convective activities in the tropics are relatively weak during the Northern Hemisphere summer season. Nitta and Sekine (1994) examined diurnal variations of convective activities in the tropical western Pacific by using infrared equivalent blackbody temperature data derived from the Geostationary Meteorological Satellite (GMS). They showed that large diurnal variations of convective activities exist over continents, large islands, and their adjacent sea regions. The intensity of convective activity reaches its maximum in late afternoon to evening over land regions, and in the morning over the adjacent sea regions (see Fig. 4 of Nitta and Sekine, 1994). They also showed that diurnal variations of convective activity are very prominent over Sumatera and the adjacent sea region. Other studies also showed that diurnal variations of convective activities are prominent over Sumatera by in-situ and satellite observations. From the cloud-type classification by the Boundary Layer Radar (BLR), Renggono et al. (2001) showed that diurnal variations of convective activities are prominent in the mountainous area in $\mathrm{Su}-$ matera. They showed that convective clouds tend to develop from 13:00 LT to 21:00 LT, and that after the decay of convective clouds, stratiform clouds develop until early morning ( 06:00 LT). From observations by GPS-derived precipitable water, radiosondes, and surface weather station, Wu et al. (2003) showed that a rainfall event often occurs as intensive showers during a short period in the late afternoon and early evening at the mountainous area of Sumatera, and suggested that the evaporation of water from the surface by the strong solar heating and horizontal transport of water vapor by thermally induced local circulation play an important role on diurnal variations of convective activities. Recently, Mori et al. (2004) showed time and spatial variations of rainfall around the west coast of Sumatera by using data observed by Tropical Rainfall Measuring Mission (TRMM) satellite Precipitation Radar (PR). They showed that the peak of rainfall in the daytime and nighttime migrate with time, starting from the southwestern coastline of Sumatera into the inland and offshore regions, respectively. They also used rawinsonde sounding data at two stations (coastline and mountainous area of Sumatera, respectively) and showed that diurnal variations of wind, humidity and stability in the lower troposphere agree well with the migration of rainfall peaks over both the inland and the coastal sea regions.

Several studies suggested the relation between convective activities over Sumatera and atmospheric waves (Kelvin waves and ISV). From the spectral analysis of horizontal winds observed by BLR, Widiyatmi et al. (2001) showed that oscillations of zonal wind with a period of $>10$ days are prominent over Sumatera, and suggested that these 


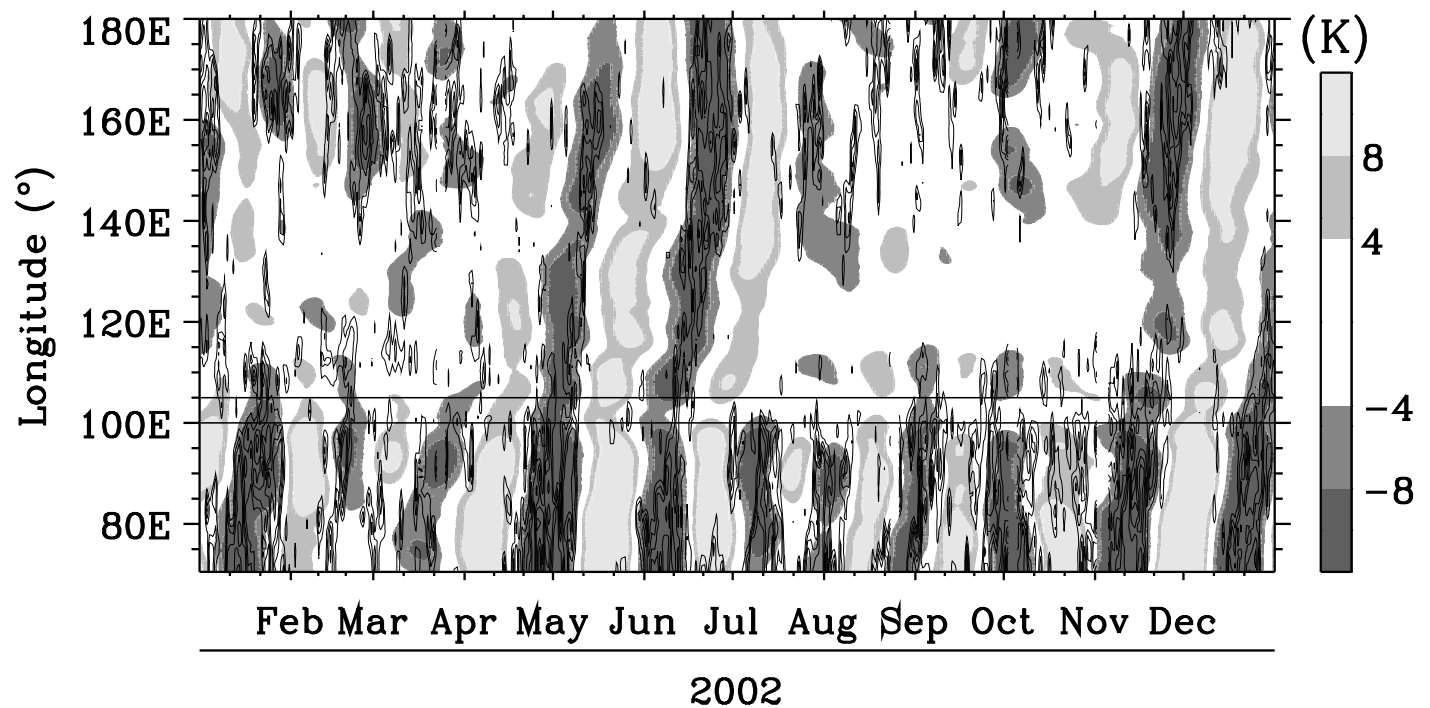

Fig. 2. Time-longitude plot of bandpass-filtered $\mathrm{T}_{\mathrm{BB}}$ with cutoffs at 25 days and 60 days (shaded) and daily-averaged $\mathrm{T}_{\mathrm{BB}}$ (solid) averaged over $2.5^{\circ} \mathrm{S}-2.5^{\circ} \mathrm{N}$ in 2002 . Solid contours begin at $260 \mathrm{~K}$, and decrease with the interval of $10 \mathrm{~K}$. The horizontal solid line shows the longitude of $100^{\circ} \mathrm{E}$ and $105^{\circ} \mathrm{E}$.

oscillations are related to Kelvin waves and/or ISVs. The relation between diurnal variations of convective activities over Sumatera caused by local circulations and large-scale convective activities by SCCs was discussed by Murata et al. (2002). From the case study during the boreal fall season (September-October 1998), they showed that diurnal and quasi-10-day variations of convective activities are prominent over the mountainous area of Sumatera, and precipitation events are frequently observed during the weak westerly phase of quasi-10-day variations of low-level (1-3 km) zonal wind. They suggested that eastward propagation of SCC is blocked at the mountainous area of Sumatera, and that precipitation at the mountainous area of Sumatera is caused mainly by the diurnal oscillation of local-scale cloud systems along the mountain range. However, observations at Sumatera are not enough even now, and further studies are necessary to understand the interactions between convective activities over Sumatera and ISVs.

A VHF radar can observe three-dimensional winds in the whole troposphere with fine time and height resolutions (e.g. Larsen and Röttger, 1982; Gage, 1990; Thomas, 1999). In the tropics, VHF radar observations have been performed over the tropical Pacific (e.g. Gage et al., 1991), and in India (Rao et al., 1995). However, an observation throughout the whole troposphere by a VHF radar has never been performed over Sumatera. The Equatorial Atmosphere Radar (EAR), installed near Bukittinggi, West Sumatera, Indonesia $\left(0.20^{\circ} \mathrm{S}, 100.32^{\circ} \mathrm{E}\right)$, can observe three-dimensional winds in the whole troposphere and the lower stratosphere $(2-20 \mathrm{~km})$ with fine time and height resolutions of $\sim 90 \mathrm{~s}$ and $150 \mathrm{~m}$, respectively (Fukao et al., 2003). EAR has been operated continuously since July 2001. Beside EAR, the surface weather station and BLR have been continuously operated at the Kototabang Global Atmospheric Watch (GAW) station which is $\sim 300 \mathrm{~m}$ away from the EAR site.

In this study, we focus on the ISV event in June 2002. During this period, SCCs, which developed over the Indian Ocean $\left(\sim 75-90^{\circ} \mathrm{E}\right)$ within the large-scale envelope convective activities in ISV, passed over Sumatera $\left(\sim 95-105^{\circ} \mathrm{E}\right)$ without significant diminution, and continued their propagation to the western Pacific. ISV's influence on convective activities over Sumatera in June 2002 will be presented in this study. In Sect. 2, we present the data used in this study. In Sect. 3, we present the overview of ISV events near Sumatera in 2002, and then present temporal and spatial variations of convective activities associated with the ISV event in June 2002. Similarities and dissimilarities of convective features between our case study over Sumatera and studies in Tropical Ocean and Global Atmosphere/Coupled Ocean-Atmosphere Response Experiment (TOGA COARE) are also discussed in this section. In Sect. 4, we show the different convective features during the inactive and active phases of ISV by using EAR, BLR, and GMS data. In Sect. 5, we present discussions and conclusions.

\section{Data}

EAR operates at $47.0 \mathrm{MHz}$ with a maximum peak and an average transmitted power of $100 \mathrm{~kW}$ and $5 \mathrm{~kW}$, respectively. EAR is located near Bukittinggi in West Sumatera, Indonesia $\left(0.20^{\circ} \mathrm{S}, 100.32^{\circ} \mathrm{E}\right)$. EAR and other instruments used in this study are installed at the mountainous area in the western side of Sumatera (see Fig. 1). Fukao et al. (2003) described the details of EAR. One beam of EAR is pointed vertically and four others are tilted to the north, east, south, and 


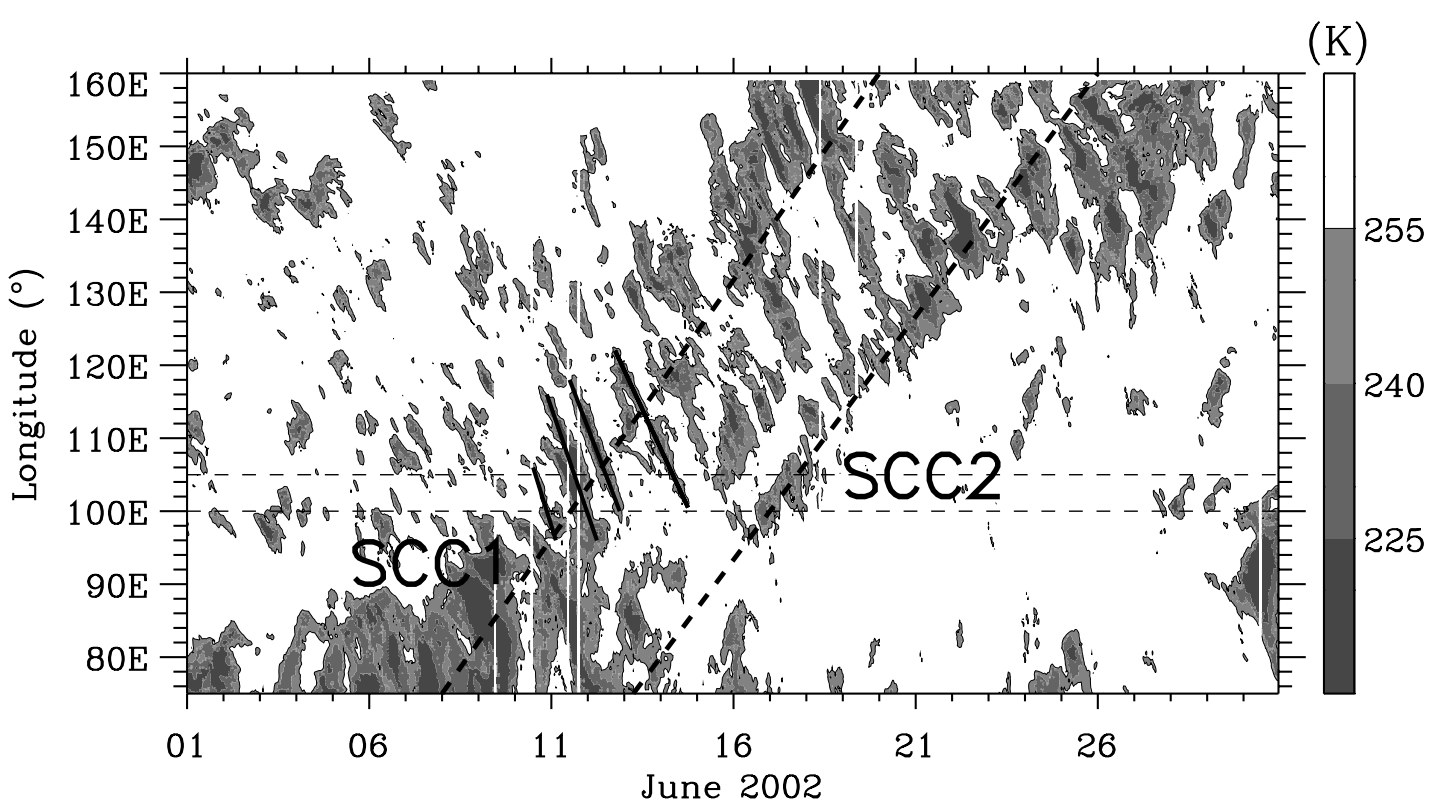

Fig. 3. Time-longitude plot of $\mathrm{T}_{\mathrm{BB}}$ averaged over $1^{\circ} \mathrm{S}-1^{\circ} \mathrm{N}$ in June 2002 . Longitudinal resolution is $0.2^{\circ}$. Thin horizontal broken lines indicate the longitude of $100^{\circ} \mathrm{E}$ and $105^{\circ} \mathrm{E}$. Thick broken lines show the propagation of SCC1 and SCC2, while thick solid lines show the propagation of CCs.

west with zenith angles of $10^{\circ}$ to observe three-dimensional wind velocities. Vertical wind is derived from the Doppler shift measured by the frequency spectrum in the verticallypointing beam. In standard observations, time and vertical resolutions are $\sim 90 \mathrm{~s}$ and $150 \mathrm{~m}$, respectively. Wind data in November 2001 and in June 2002 are used in this study.

A UHF-band wind profiler can observe winds and hydrometers in the lower troposphere, including the planetary boundary layer (PBL) (e.g. Carter et al., 1995; Ohno, 1995; Reddy et al., 2000). BLR is installed at Kototabang GAW station, which is $\sim 300 \mathrm{~m}$ away from the EAR site. It is operated at a frequency of $1357.5 \mathrm{MHz}$ with a peak transmitted power of $1 \mathrm{~kW}$ (Renggono et al., 2001). BLR is designed to observe winds in the lower troposphere, including the PBL with time and vertical resolutions of $\sim 1$ min and $100 \mathrm{~m}$, respectively (Hashiguchi et al., 1995). Although BLR is designed to observe winds in the clear air, earlier studies showed that BLR can also be used to detect hydrometers. From BLR observations at Kototabang GAW station, Renggono et al. (2001) have shown that BLR can classify precipitating cloud types by slightly modifying the algorithm proposed by Williams et al. (1995).

Surface data (rainfall amount, pressure, solar radiation, temperature, and relative humidity) observed at Kototabang GAW station are also used in this study. During June 2002, surface data were recorded every $1 \mathrm{~min}$.

Blackbody brightness temperature data observed by GMS IR1 sensor $(11.5 \mu \mathrm{m})$ (hereafter $\mathrm{T}_{\mathrm{BB}}$ ) are used for investigating the horizontal distribution of cloud tops. The original spatial and time resolutions of $\mathrm{T}_{\mathrm{BB}}$ are $0.05^{\circ} \times 0.05^{\circ}$ and one hour, respectively.
Horizontal wind data derived from NCEP/NCAR (National Center for Environmental Prediction/National Center for Atmospheric Research) reanalysis (hereafter NCEP horizontal wind) are also used for examining temporal and spatial variations of ISV. NCEP horizontal winds are also used for comparing them with the horizontal winds observed by EAR.

During 1-28 November 2001, intensive radiosonde observations were carried out at Kototabang GAW station (Mori et al., 2004). Height profiles of temperature and humidity obtained by radiosondes are used to compute the $\mathrm{K}$ index (a convective index), which is compared with the time and height variations of the variance of vertical wind observed by EAR.

\section{Eastward-propagating convective systems in June 2002}

\subsection{Intraseasonal variations in 2002}

To begin with, we discuss convective activities around $\mathrm{Su}-$ matera and its relation to ISV in 2002. Because Madden (1986) reported a wide variety of the period of ISV, we applied a band-pass filtering with cutoffs at 25 days and 60 days to $\mathrm{T}_{\mathrm{BB}}$ data and examined the activity of ISVs. Figure 2 shows time-longitude plots of bandpass-filtered $\mathrm{T}_{\mathrm{BB}}$ with cutoffs at 25 days and 60 days (hereafter 25-60 day $\mathrm{T}_{\mathrm{BB}}$ ) and daily-averaged $T_{B B}$ in 2002. Both of band-pass-filtered $T_{B B}$ and daily-averaged $\mathrm{T}_{\mathrm{BB}}$ are averaged over $2.5^{\circ} \mathrm{S}-2.5^{\circ} \mathrm{N}$. Sumatera exists between $100^{\circ} \mathrm{E}$ and $105^{\circ} \mathrm{E}$ near the equator, as is indicated by solid lines. 
Throughout the year, active ISV signals, defined by $25-60$ day $\mathrm{T}_{\mathrm{BB}}$, develop over the Indian Ocean with an amplitude of $<-4 \mathrm{~K}$. Part of the ISVs propagate from the Indian Ocean to the western Pacific without significant diminution over the maritime continent $\left(100-120^{\circ} \mathrm{E}\right)$, as seen in cases during 20 April-20 May, 1 June-1 July, and 1 November-1 December. Meanwhile, other active ISV signals over the equator dissipate near Sumatera or over the Indian Ocean (especially around $\sim 100^{\circ} \mathrm{E}$ longitude), as seen in the case during 5-25 January, 10 March-1 April, 1-20 July, 25 July-10 August, 20 August-10 September, and 20 September-10 October. Wang and Rui (1990) showed that part of the ISVs which propagate eastward at the equator in the Indian Ocean turn northeast to the northwest Pacific (NE mode) or southeast to the southwest Pacific (SE mode) over the maritime continent. These modes contribute to dissipations of ISVs near Sumatera.

Over the Indian Ocean $\left(70-100^{\circ} \mathrm{E}\right)$, daily-averaged $\mathrm{T}_{\mathrm{BB}}$ with high cloud tops of $<260 \mathrm{~K}$ (or higher than $\sim 7 \mathrm{~km}$ ) is observed during the active phase of ISV. Although the enhancement of convective activities are observed over the Indian Ocean, even in the inactive phase ISV (e.g. 10 to 31 October), the enhancement of convective activities over the Indian Ocean $\left(70-100^{\circ} \mathrm{E}\right)$ as is seen in daily-averaged $\mathrm{T}_{\mathrm{BB}}$ generally occurs in the active phase of ISVs. Dunkerton and Crum (1995) showed the consistent result by using outgoing longwave radiation (OLR) data. In this paper, we focus on the ISV event where convective activities over Sumatera are significantly modulated by the ISV. In June 2002 , the envelope of the active phase of ISV with cloud tops of $<260 \mathrm{~K}$ develops over the Indian Ocean, then propagates eastward to the western Pacific with a slight diminution over Sumatera $\left(100-105^{\circ} \mathrm{E}\right)$. Hereafter in this paper, we focus on the ISV event in June 2002, and investigate features of convective activities over Sumatera in difference phases of ISV.

\subsection{Intraseasonal variation over Sumatera in June 2002}

\subsubsection{IR blackbody brightness temperature observed by GMS}

\section{Temporal and spatial variations of IR blackbody brightness temperature}

We examine temporal and spatial variations of convective activities over the Indian Ocean, the maritime continent, and the western Pacific during June 2002 by using $\mathrm{T}_{\mathrm{BB}}$ data. Figure 3 shows the time-longitude plot of $\mathrm{T}_{\mathrm{BB}}$ averaged over $1^{\circ} \mathrm{S}-1^{\circ} \mathrm{N}$ during June 2002. A large envelope of enhanced convective activities with $\mathrm{T}_{\mathrm{BB}}<255 \mathrm{~K}(\sim 8 \mathrm{~km})$ exists over the Indian Ocean $\left(\sim 70-90^{\circ} \mathrm{E}\right)$ in early June. It propagates eastward in the middle of June, and reaches the western Pacific $\left(\sim 130-160^{\circ} \mathrm{E}\right)$ in the last half of June. We defined SCC as an eastward-propagating cloud cluster with 3-day averaged $\mathrm{T}_{\mathrm{BB}}$ of $<260 \mathrm{~K}$ and with a spatial scale of $>1000 \mathrm{~km}$. Figure 4 shows the longitude-latitude plots of $\mathrm{T}_{\mathrm{BB}}$ averaged over 4-6, 10-12, 15-17, and 24-26 in June 2002, respectively. During 4-6 June, first SCC (hereafter SCC1) exists around $70-90^{\circ} \mathrm{E}$ (Fig. 4a). SCC1 then propagates eastward (a) 4-6 June

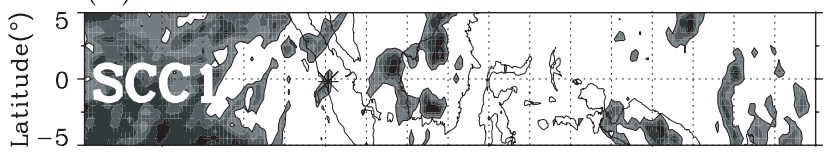

(b) $10-12$ June

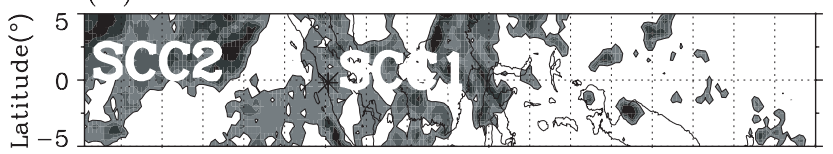

(c) $15-17$ June
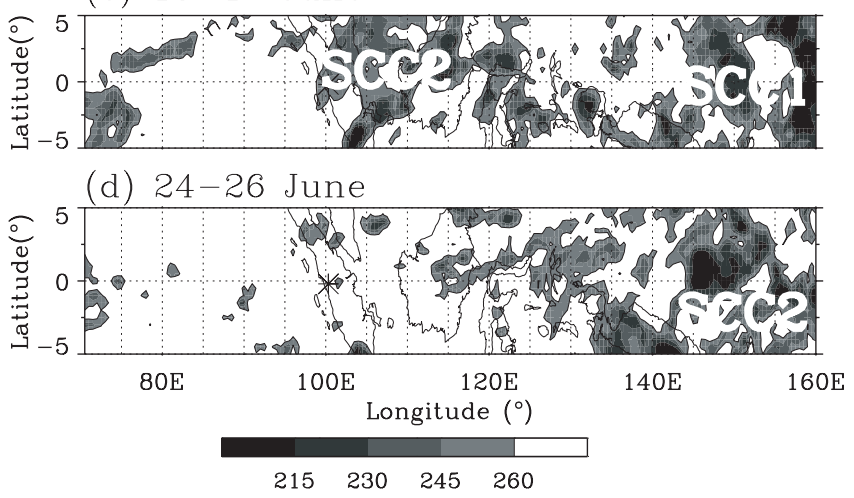

(K)

Fig. 4. Longitude-latitude plots of $\mathrm{T}_{\mathrm{BB}}$ averaged over (a) 4-6, (b) 10-12, (c) 15-17, and (d) 24-26 in June 2002. “*” in each panel indicates the location of the observation site.

and exists over the maritime continent $\left(100-120^{\circ} \mathrm{E}\right)$ during 10-12 June. Meanwhile, a second SCC (hereafter SCC2) is formed around $70-90^{\circ} \mathrm{E}$ during the same period (Fig. 4b). During 15-17 June, SCC1 further propagates to the western Pacific $\left(140-160^{\circ} \mathrm{E}\right)$, and SCC2 propagates eastward from the Indian Ocean to the maritime continent (Fig. 4c). During 24-26 June, SCC2 further propagates eastward, and exists over the western Pacific (Fig. 4d). We defined CC as a westward-propagating cloud cluster with $\mathrm{T}_{\mathrm{BB}}$ of $<255 \mathrm{~K}$, a spatial scale of $>200 \mathrm{~km}$, and a time scale of $>1$ day. During 10-14 June, CCs with $\mathrm{T}_{\mathrm{BB}}<255 \mathrm{~K}$ develop in the envelope of SCC1, and pass over Sumatera with an interval of 1-2 days (on 10, 11, and 14 June). During 16-17 June, enhanced convective activities with $\mathrm{T}_{\mathrm{BB}}<255 \mathrm{~K}$ exist over Sumatera within the envelope of the active phase of SCC2. Convective activities over Sumatera are enhanced several times with $\mathrm{T}_{\mathrm{BB}}<240 \mathrm{~K}(\sim 10 \mathrm{~km})$. Their lifetimes are $<1$ day, and do not show clear westward propagation. However, when SCC2 reaches the western Pacific $\left(130-160^{\circ} \mathrm{E}\right)$, clear westward propagation of $\mathrm{CCs}$ are observed (e.g. from $160^{\circ} \mathrm{E}$ on 24 June to $130^{\circ} \mathrm{E}$ on 26 June).

\section{Temporal variations of IR blackbody brightness temperature over Sumatera}

We classify the observation period into three periods to discuss features of convective activities over Sumatera in different phases of ISV. Figure 5 shows time variations of $T_{B B}$, 


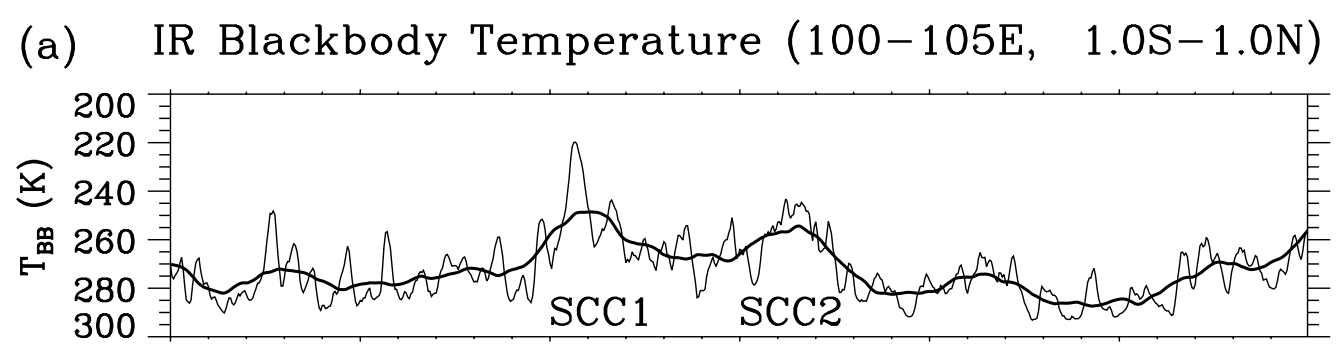

(b)

850hPa NCEP Zonal Wind

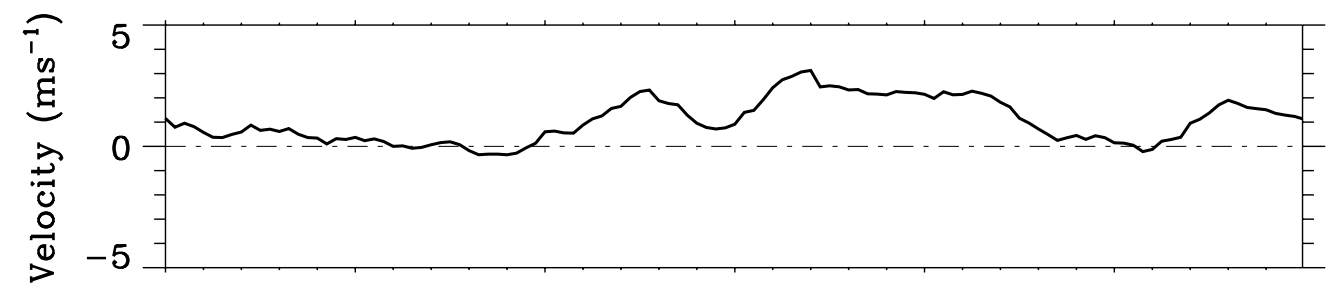

(c) Vertical Shear between $700 \mathrm{hPa}$ and $150 \mathrm{hPa}$

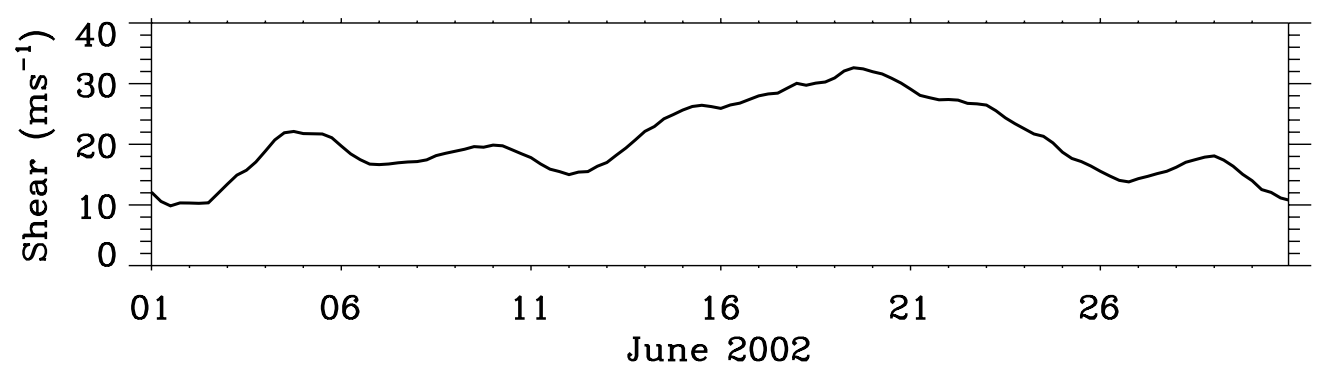

Fig. 5. Time variations of (a) $\mathrm{T}_{\mathrm{BB}}$, (b) zonal wind at $850 \mathrm{hPa}$, and (c) vertical shear of horizontal wind between $700 \mathrm{hPa}$ and $150 \mathrm{hPa}$. Wind data are derived from NCEP/NCAR reanalysis. In panel (a), $\mathrm{T}_{\mathrm{BB}}$ is averaged over $100^{\circ} \mathrm{E}-105^{\circ} \mathrm{E}$ longitudinally and $1^{\circ} \mathrm{S}-1^{\circ} \mathrm{N}$ latitudinally. Thick solid curve shows $\mathrm{T}_{\mathrm{BB}}$ smoothed by 2-day running mean, and thin solid curve shows $\mathrm{T}_{\mathrm{BB}}$ observed every one hour. In panels (b) and (c), zonal wind at $850 \mathrm{hPa}$ and vertical shear of horizontal wind between $700 \mathrm{hPa}$ and $150 \mathrm{hPa}$ are averaged over $100^{\circ} \mathrm{E}-105^{\circ} \mathrm{E}$ longitudinally and $2.5^{\circ} \mathrm{S}-2.5^{\circ} \mathrm{N}$ latitudinally. Zonal wind at $850 \mathrm{hPa}$ and vertical shear of horizontal wind between $700 \mathrm{hPa}$ and $150 \mathrm{hPa}$ are smoothed by 2-day running mean.

zonal wind at $850 \mathrm{hPa}$, and vertical shear of horizontal wind between $700 \mathrm{hPa}$ and $150 \mathrm{hPa}$ derived from NCEP/NCAR reanalysis over the equatorial area of Sumatera. We selected levels of $700 \mathrm{hPa}$ and $150 \mathrm{hPa}$ to compute the vertical shear of horizontal wind in the troposphere, because vertical shear of horizontal wind between $700 \mathrm{hPa}$ and $150 \mathrm{hPa}$ has the largest correlation with variations in the Geostationary Operational Environmental Satellite (GOES) precipitation Index (GPI) during TOGA COARE (Saxen and Rutledge, 2000). Zonal wind at $850 \mathrm{hPa}$ and vertical shear of horizontal wind between $700 \mathrm{hPa}$ and $150 \mathrm{hPa}$ are smoothed by a 2-day running mean.

During 1-9 June, weak zonal wind $\left(<1 \mathrm{~m} \mathrm{~s}^{-1}\right)$ at $850 \mathrm{hPa}$ and a gradual decrease of $\mathrm{T}_{\mathrm{BB}}$ are seen over Sumatera. Smoothed $\mathrm{T}_{\mathrm{BB}}$ decreases from $\sim 280 \mathrm{~K}$ on 2 June to $\sim 270 \mathrm{~K}$ on 9 June, with several convective events with $\mathrm{T}_{\mathrm{BB}}<265 \mathrm{~K}$. Vertical shear of horizontal wind between $700 \mathrm{hPa}$ and $150 \mathrm{hPa}$ increases from $\sim 10 \mathrm{~m} \mathrm{~s}^{-1}$ (on 2 June) to $\sim 20 \mathrm{~m} \mathrm{~s}^{-1}$ (on 9 June).
During 10-19 June, increase of westerlies, increase of vertical shear of horizontal wind, and intensified convective activities by SCCs are seen over Sumatera. When we define the longitude at which the highest cloud top is located as the location of the center of SCC, the center of SCC1 and SCC2 pass over Sumatera on 11 and 17 June, respectively. During $10-13$ June, westerly at $850 \mathrm{hPa}$ increases up to $\sim 2.5 \mathrm{~m} \mathrm{~s}^{-1}$ with the passage of SCC1 over Sumatera. $\mathrm{T}_{\mathrm{BB}}$ decreases rapidly until it reaches to $\sim 219 \mathrm{~K}(\sim 12.5 \mathrm{~km})$ on 11 June with the passage of a well-developed CC within the envelope of SCC1 (also see Fig. 3). After 13 June, westerly at $850 \mathrm{hPa}$ decreases until it reaches $\sim 1 \mathrm{~m} \mathrm{~s}^{-1}$ on 15 June. Convective activities inferred from $\mathrm{T}_{\mathrm{BB}}$ become weaker during 13-15 June. Westerly at $850 \mathrm{hPa}$ increases again with the passage of SCC 2 over Sumatera after 15 June. With the increase of westerly at $850 \mathrm{hPa}, \mathrm{T}_{\mathrm{BB}}$ rapidly decreases until it reaches a peak of $\sim 243 \mathrm{~K}(\sim 9.7 \mathrm{~km})$ on 17 June, when the center of SCC2 passes over Sumatera. After the passage of the center of SCC2 over Sumatera, westerly at $850 \mathrm{hPa}$ 
reaches a maximum of $\sim 3 \mathrm{~m} \mathrm{~s}^{-1}$ during 17-18 June. Though westerly increases only up to $\sim 3 \mathrm{~m} \mathrm{~s}^{-1}$ at $850 \mathrm{hPa}$, a westerly wind burst of $>12 \mathrm{~m} \mathrm{~s}^{-1}$ is observed at $2-3 \mathrm{~km}$ altitude during 17-18 June (see Fig. 7). Westerly at $850 \mathrm{hPa}$ is large $\left(>8 \mathrm{~m} \mathrm{~s}^{-1}\right)$ in the Indian Ocean $\left(70-90^{\circ} \mathrm{E}\right)$ in the first half of June, but it is weakened over the maritime continent (100$120^{\circ} \mathrm{E}$ ), probably due to the topographic effect (not shown). Convective activities over Sumatera rapidly weaken with the occurrence of a westerly wind burst. $\mathrm{T}_{\mathrm{BB}}$ gradually increases during 17-18 June, and reaches to $\sim 280 \mathrm{~K}$ on 19 June. Vertical shear of horizontal wind between $700 \mathrm{hPa}$ and $150 \mathrm{hPa}$ continues to increase from 10 June, and reaches the maximum of $32 \mathrm{~m} \mathrm{~s}^{-1}$ on 19 June.

During 20-26 June, a decrease of westerlies, a decrease of vertical shear of horizontal wind in the troposphere, and a suppression of convective activities are seen over Sumatera. Strong westerly of $\sim 2 \mathrm{~m} \mathrm{~s}^{-1}$ at $850 \mathrm{hPa}$ prevails during 20-22 June, then it decreases until it reaches $\sim 0 \mathrm{~m} \mathrm{~s}^{-1}$ on 26 June. Vertical shear of horizontal wind between $700 \mathrm{hPa}$ and $150 \mathrm{hPa}$ decreases from 19 June, and reach the minimum of $14 \mathrm{~m} \mathrm{~s}^{-1}$ on 26 June. Convective activities are suppressed over Sumatera during 20-26 June as inferred from high $\mathrm{T}_{\mathrm{BB}}$ of $>270 \mathrm{~K}$. After 27 June, with the increase of westerly at $850 \mathrm{hPa}$, the gradual enhancement of convective activities over Sumatera is observed again, as inferred from temporal variations of $\mathrm{T}_{\mathrm{BB}}$ over Sumatera.

From temporal variations of $\mathrm{T}_{\mathrm{BB}}$, zonal wind at $850 \mathrm{hPa}$, and vertical shear of horizontal wind between $700 \mathrm{hPa}$ and $150 \mathrm{hPa}$ as mentioned above, we classify the whole observation period as follows:

- Period 1 (1-9 June): Zonal wind at $850 \mathrm{hPa}$ is weak $\left(<1 \mathrm{~m} \mathrm{~s}^{-1}\right)$, and cloud tops increase gradually with several enhancements of convective activities. The vertical shear of horizontal wind between $700 \mathrm{hPa}$ and $150 \mathrm{hPa}$ increases from $\sim 10 \mathrm{~m} \mathrm{~s}^{-1}$ to $\sim 20 \mathrm{~m} \mathrm{~s}^{-1}$. This period is classified into the inactive phase of ISV.

- Period 2 (10-19 June): During 10-17 June, westerly at $850 \mathrm{hPa}$ increases twice with passages of SCC1 and SCC2, and high cloud tops with $\mathrm{T}_{\mathrm{BB}}$ of $<270 \mathrm{~K}$ are dominant. From 17 June, awesterly wind burst occurs and convective activities weaken rapidly. The vertical shear of horizontal wind between $700 \mathrm{hPa}$ and $150 \mathrm{hPa}$ increases from $\sim 20 \mathrm{~m} \mathrm{~s}^{-1}$ to $\sim 32 \mathrm{~m} \mathrm{~s}^{-1}$. This period is classified into the active phase of ISV.

- Period 3 (20-26 June): Strong westerly of $\sim 2 \mathrm{~m} \mathrm{~s}^{-1}$ at $850 \mathrm{hPa}$ prevails during 20-22 June, then it decreases until it reaches $\sim 0 \mathrm{~m} \mathrm{~s}^{-1}$ on 26 June. Convective activities are suppressed. The vertical shear of horizontal wind between $700 \mathrm{hPa}$ and $150 \mathrm{hPa}$ continues to decrease. This period is classified into the postwesterly wind burst phase of ISV.

The enhancement of convective activities, which exists in organized SCCs, lasts $\sim 10$ days (10-19 June) in our case. This is consistent with the typical time scale (10-15 days) (a) Zonal wind

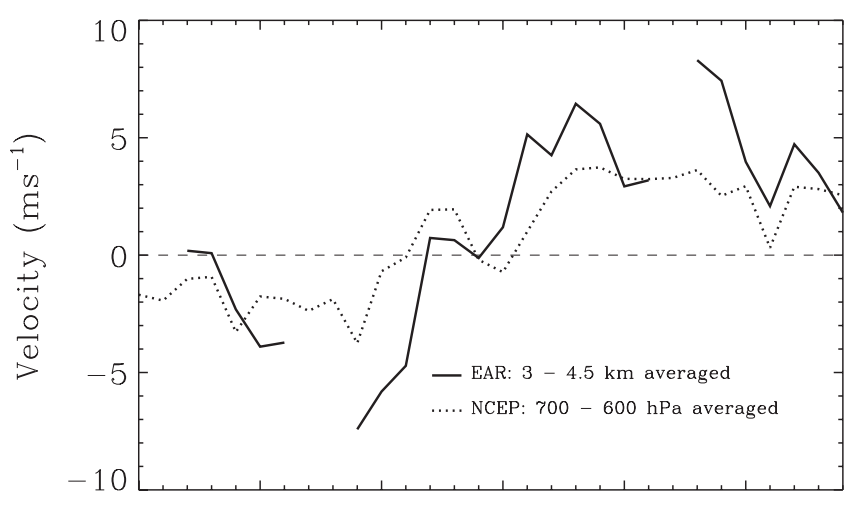

(b) Meridional wind

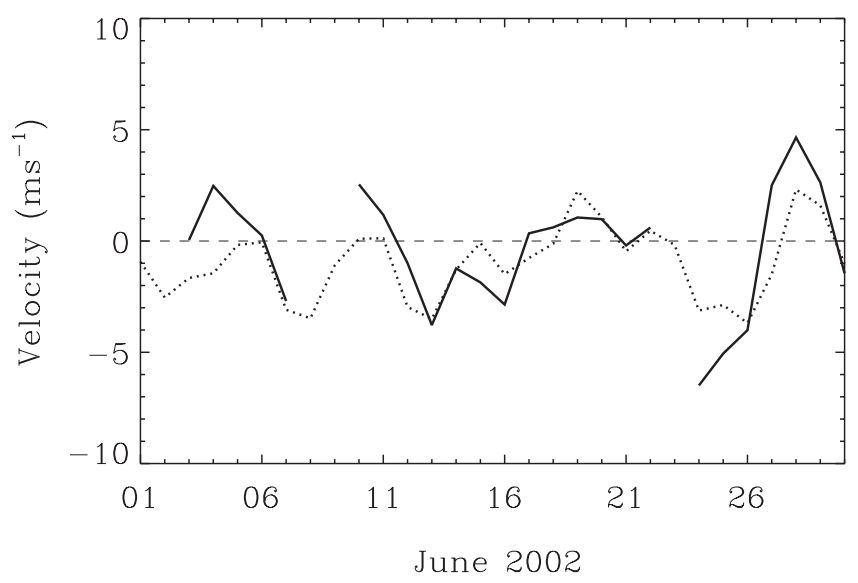

Fig. 6. Time variations of (a) zonal and (b) meridional wind derived from EAR and NCEP/NCAR reanalysis. Solid and dotted curves show EAR winds averaged in $3-4.5 \mathrm{~km}$ and NCEP winds averaged in $700-600 \mathrm{hPa}$ closest to the observation site $\left(0^{\circ} \mathrm{N}, 100^{\circ} \mathrm{E}\right)$, respectively.

of the organization of SCCs (Lau et al., 1991). Henceforth in this paper, we discuss temporal variations of convective activities over Sumatera by using the classification of Periods $1-3$.

Temporal variations of convective activities over Sumatera by ISV have features in common with those found during TOGA COARE. They are summarized as follows:

- During the inactive phase of ISV (Period 1), convective activities as inferred from $\mathrm{T}_{\mathrm{BB}}$ gradually strengthen. This suggests that some mechanisms that gradually moisten the middle and upper troposphere exist. During TOGA COARE, isolated convective cells which repeatedly penetrate into the middle and upper troposphere and moisten the air play an important role in creating favorable conditions for the organization of large-scale convective systems (Redelsperger et al., 2002; Demott and Rutledge, 1998a, b).

- The maximum intensity of convective activities as inferred from $\mathrm{T}_{\mathrm{BB}}$ occurs during 10-17 June, and it 


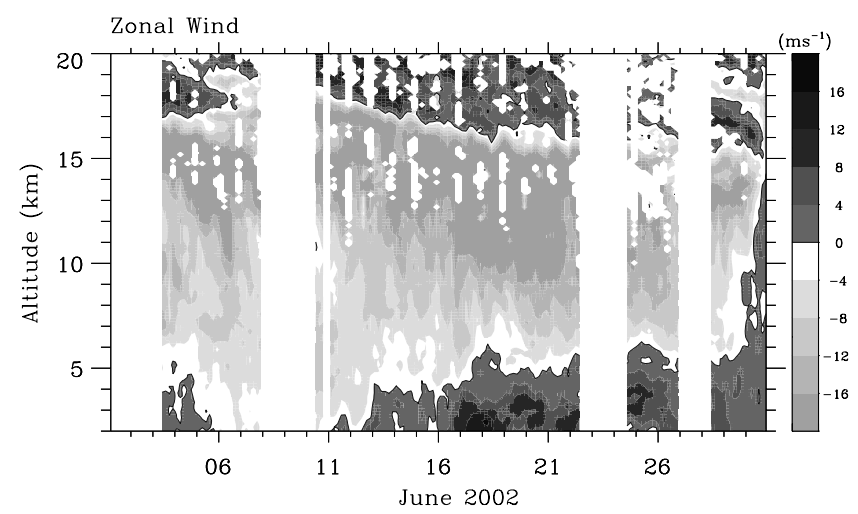

Fig. 7. Time-altitude plot of zonal wind observed by EAR in June 2002.

precedes the maximum of the westerly wind burst (1718 June). This is consistent with model studies (e.g. Lau et al., 1989) and observational studies over the western Pacific during TOGA COARE (Rickenbach and Rutledge, 1998; Lin and Johnson, 1996). Moderate vertical shear of horizontal wind $\left(20-30 \mathrm{~m} \mathrm{~s}^{-1}\right)$ plays an important role in the organization of mesoscale convective activities with a horizontal scale of $>100 \mathrm{~km}$ (Saxen and Rutledge, 2000; Rickenbach and Rutledge, 1998).

Our case study during June 2002 shows similar features found in TOGA COARE. However, a dissimilarity is also observed between our case study and TOGA COARE. During TOGA COARE, mesoscale convective events are observed 2-5 days after the maximum of the westerly wind burst (Rickenbach and Rutledge, 1998). However, in our case study, a well-organized convective event is not observed during the postwesterly wind burst phase of the ISV (Period 3). Furthermore, different features may exist in our case study because Sumatera is located at the eastern edge of the Indian Ocean and has the high mountainous range in its western side. Interactions of the ocean and land may cause different features of convective activities within ISV from those in TOGA COARE, because observations of TOGA COARE are carried out over the open ocean in the western Pacific. Henceforth in this paper, we will also focus on dissimilarities of convective activities associated with ISV between TOGA COARE and our case study.

\subsubsection{Zonal wind observed by EAR}

\section{Comparison of horizontal wind derived from EAR and NCEP/NCAR reanalysis}

We examined time and height variations of zonal wind observed by EAR during June 2002. Before investigating them, we first examined whether horizontal wind observed by EAR agrees well with that derived from NCEP/NCAR reanalysis. Figure 6 shows time variations of daily-averaged horizontal wind observed by EAR and NCEP horizontal wind at

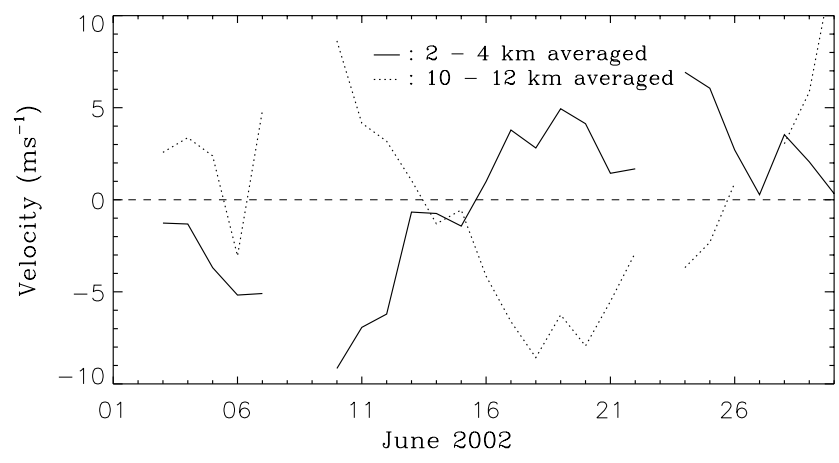

Fig. 8. Time variation of zonal wind anomalies averaged in $2-4 \mathrm{~km}$ (solid curve) and 10-12 km (dotted curve) observed by EAR in June 2002.

the grid closest to the observation site $\left(100^{\circ} \mathrm{E}, 0^{\circ} \mathrm{N}\right)$ during June 2002. The distance between the observation site and the closest grid of NCEP reanalysis $\left(100^{\circ} \mathrm{E}, 0^{\circ} \mathrm{N}\right)$ is $\sim 40 \mathrm{~km}$. NCEP horizontal wind is averaged over $700-600 \mathrm{hPa}$ levels, and EAR horizontal wind is averaged over the equivalent altitude range $(3-4.5 \mathrm{~km})$. Note that EAR was not operated during 1-2, 8-9, and 23 June 2002, mainly due to power failures. Though the amplitude of EAR horizontal wind tends to be larger than NCEP horizontal wind, its tendency of time variations agrees well with NCEP horizontal wind. It should be noted that operational rawinsonde observations are carried out at only three stations on Sumatera. They are located at Padang $\left(0.88^{\circ} \mathrm{S}, 100.35^{\circ} \mathrm{E}\right)$, Medan $\left(3.57^{\circ} \mathrm{N}\right.$, 98.68 $\mathrm{E})$, and Pangkal Pinang $\left(2.17^{\circ} \mathrm{S}, 106.13^{\circ} \mathrm{E}\right)$, respectively (Okamoto et al., 2003). Routine rawinsonde soundings are carried out once every two days, and observational results of routine radiosonde soundings are used for NCEP/NCAR reanalysis (Mori et al., 2004). Though observations carried out for NCEP/NCAR reanalysis are very scarce over Sumatera, horizontal wind observed by EAR and that derived from NCEP/NCAR reanalysis show a good coincidence. Also, it can be concluded that horizontal wind observed by EAR well represents the large-scale $\left(2.5^{\circ} \times 2.5^{\circ}\right)$ wind field as derived from NCEP/NCAR reanalysis.

\section{Time and altitude variations of zonal wind observed by EAR}

Figure 7 shows the time-altitude plot of zonal wind observed by EAR during June 2002. Zonal wind is averaged every $4 \mathrm{~h}$. During Period 1, zonal wind at $2-4 \mathrm{~km}$ altitude (hereafter low-level zonal wind) is easterly or weak westerly. During Period 2, low-level westerly continuously increases, and westerly wind burst is observed on 17-18 June. The westerly wind burst has a maximum of $>12 \mathrm{~m} \mathrm{~s}^{-1}$ at $2-3 \mathrm{~km}$ altitude. During Period 3, westerly of $>4 \mathrm{~m} \mathrm{~s}^{-1}$ prevails at 2$4 \mathrm{~km}$ altitudes. To further investigate time variations of zonal wind in the lower troposphere and upper troposphere, we computed the zonal wind anomalies averaged over $2-4 \mathrm{~km}$ altitudes (lower troposphere) and over 10-12 km altitudes (upper troposphere). Zonal wind anomalies are computed 


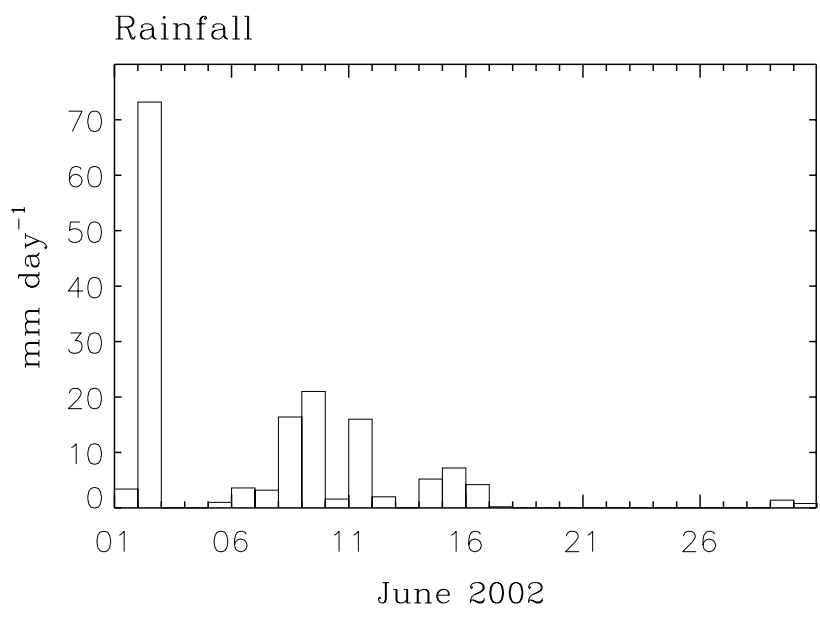

Fig. 9. Daily rainfall amount observed at Kototabang GAW station in June 2002.

as a deviation from the monthly average values observed by EAR during June 2002. The result is shown in Fig. 8. Negative correlation between zonal wind averaged over $2-4 \mathrm{~km}$ altitudes and one averaged over $10-12 \mathrm{~km}$ altitudes are very clear. During Period 1, when convective activities are gradually strengthened over Sumatera (see Fig. 5a), anomalous easterly at $2-4 \mathrm{~km}$ is observed. When enhanced convective activities with $\mathrm{T}_{\mathrm{BB}}$ of $<270 \mathrm{~K}$ are continuously observed over Sumatera (11-17 June; see Figs. 3 and 5a), anomalous easterly gradually changes to westerly. During Period 3 , anomalous westerly is dominant at $2-4 \mathrm{~km}$ altitudes, and convective activities are suppressed over Sumatera. Both changes in convective activities are associated with changes in zonal wind at $2-4 \mathrm{~km}$ altitudes, and the negative correlation of zonal winds between the lower troposphere and upper troposphere agree well with the structure of the moist Kelvin wave shown by many other studies (e.g. Wang, 1988). On the other hand, the meridional wind oscillation has a period of $\sim 7$ days, and is independent of eastward-propagating SCCs (see Figs. 3, 5, and 6b).

\subsubsection{Surface meteorology}

We further investigate temporal variations of surface data (daily rainfall amount, pressure, specific humidity, temperature, and solar radiation) in June 2002. Figure 9 shows the daily rainfall amount observed at the Kototabang GAW station during June 2002. During Period 1, rainfall events are observed every day except on 3 and 4 June. The largest rainfall amount of $73 \mathrm{~mm} \mathrm{day}^{-1}$ is observed on 2 June, and a relatively large amount of rainfall $\left(>15 \mathrm{~mm} \mathrm{day}^{-1}\right)$ is also observed on 8 and 9 June. During Period 2, rainfall events are observed when $\mathrm{CC}$ s which develop in SCC1 exist over the observation site on 10-12 and 14 (see Fig. 3). A relatively large rainfall amount of $18 \mathrm{~mm} \mathrm{day}^{-1}$ is observed on 11 June. Rainfall events are also observed on 15 and 16 June, when convective activities are enhanced in SCC2.
Table 1. Averaged values of surface data at the Kototabang GAW station in June 2002.

\begin{tabular}{ll}
\hline Pressure & $917.2 \mathrm{hPa}$ \\
Specific humidity & $16.1 \mathrm{~g} \mathrm{~kg}^{-1}$ \\
Solar radiation & $177 \mathrm{~W} \mathrm{~m}^{-2}$ \\
Air temperature & $295.1^{\circ} \mathrm{K}$ \\
\hline
\end{tabular}

However, rainfall events are not observed at the observation site on 17 June, though cloud-tops with $\mathrm{T}_{\mathrm{BB}}$ of $<255 \mathrm{~K}$ are observed over Sumatera. During Period 3, no rainfall is observed. Though the rain gauge over the observation site cannot observe all of the rainfall events which exist over $\mathrm{Su}-$ matera, rainfall events observed over the observation site are strongly modulated by ISV. Rainfall rate changes greatly depending on whether a rainfall event is convective or stratiform. During Period 1, convective rainfall events caused by local circulations are dominant over the observation site. On the other hand, both convective and stratiform rainfall events are observed during period 2. On 11 June, the stratiform rainfall event caused by the passage of a well-developed CC is observed over the observation site. When rainfall events caused by the passage of SCC2 are observed at the observation site (15-16 June), both shallow and deep convective events are observed. In the next section, the relationship between rainfall rate and precipitation types over the observation site are examined in detail by using data observed by EAR, BLR, and GMS.

Figure 10 shows temporal variations of anomalous pressure, specific humidity, solar radiation, and temperature observed by the surface weather station at Kototabang GAW station in June 2002. Anomalies of surface data are computed as a deviation from the monthly average values shown in Table 1. Diurnal variations are prominent in all anomalous pressure, specific humidity, solar radiation, and temperature measurements. Surface pressure is significantly affected by ISV and two SCCs which pass over Sumatera during Period 2. As seen in Fig. 10a, low surface pressure is dominant during Periods 1 and 2 (1-19 June). Conversely, high surface pressure is observed during Period 3. Figure 11 shows the longitude-latitude plots of divergence at $1000 \mathrm{hPa}$ averaged during Periods 1 and 3. Horizontal wind at $1000 \mathrm{hPa}$ are derived from NCEP/NCAR reanalysis, and band-pass filtering, with cutoffs at 10 days and 60 days, and a $5^{\circ} \times 5^{\circ}$ running mean are applied. During Period 1, convergence prevails over $75-135^{\circ}$ E. Relatively strong convergence of $>5.0 \times 10^{-7}$ exists over Sumatera. Divergence prevails over $150-180^{\circ}$ E longitude. During Period 3, convergence field prevails over $145-180^{\circ} \mathrm{E}$, and divergence prevails over 80 $140^{\circ} \mathrm{E}$. Divergence of $>5.0 \times 10^{-7}$ prevails over the Indian Ocean and the western side of Sumatera. Both the existence of convergence during Period 1 and the divergence during Period 3 agree well with observed low surface pressure during Period 1 and high surface pressure during Period 3. It is 
(a) Pressure anomaly

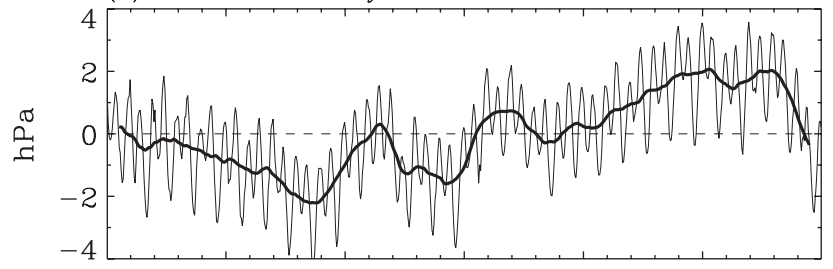

(b) Specific humidity anomaly

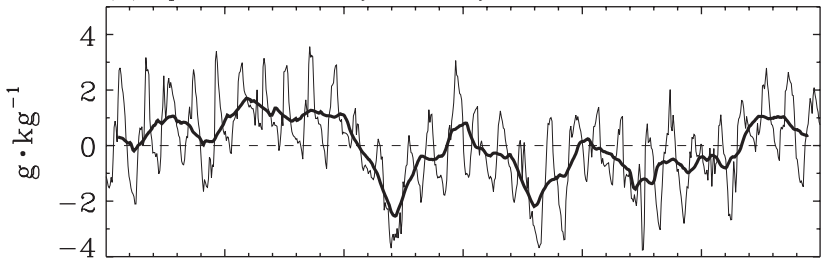

(c) Solar radiation anomaly

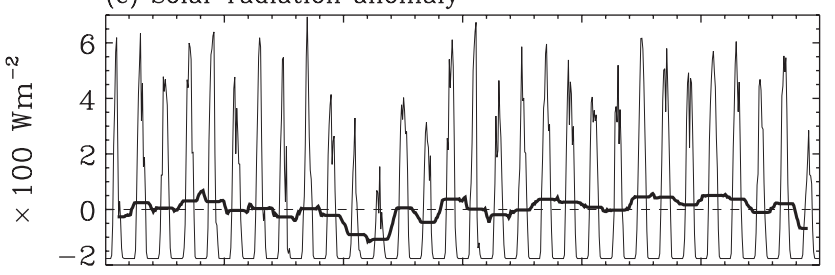

(d) Temperature anomaly

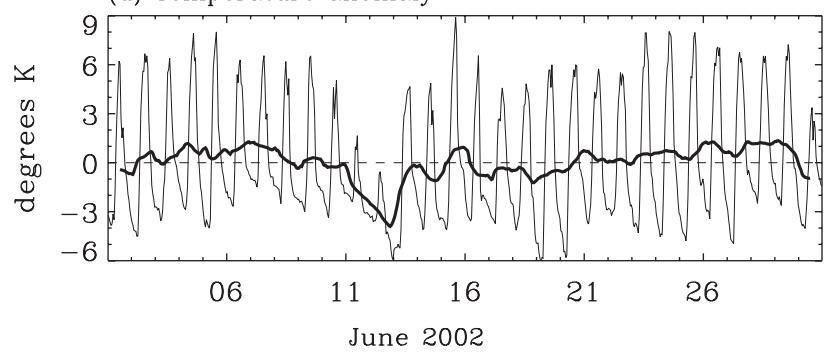

Fig. 10. Anomalies of surface (a) pressure, (b) specific humidity, (c) solar radiation, and (d) temperature observed at Kototabang GAW station in June 2002. Thin curves show values averaged every hour, and thick curves show smoothed values by 24 -hour running mean.

also consistent with the Kelvin-wave-like structure of ISV in zonal wind observed by EAR (see Fig. 8).

Temporal changes of surface pressure are also affected by passages of SCC1 and SCC2 over Sumatera. Prior to the arrival of the center of SCC1 on 11 June, surface pressure decreases gradually until it reaches a negative peak on 9 June. Hendon and Salby (1994) have shown that surface convergence precedes the center of enhanced convective events in the structure of ISV, and our result is consistent with theirs (see Figs. 5 and 10a). Then surface pressure increases rapidly until it reaches around the average on 12 June with the passage of the center of SCC1 over Sumatera. After 13 June, it decreases again until it reaches a negative peak on 15 June with the approach of SCC2 to Sumatera. The second negative peak of surface pressure on 15 June also precedes the arrival of the center of SCC2 to Sumatera on 17 June. High surface pressure is observed during 18-30 June. However, during 27 to 30 June, surface pressure decreases and convective ac- (a) Divergence Period 1 (1-9 June 2002)

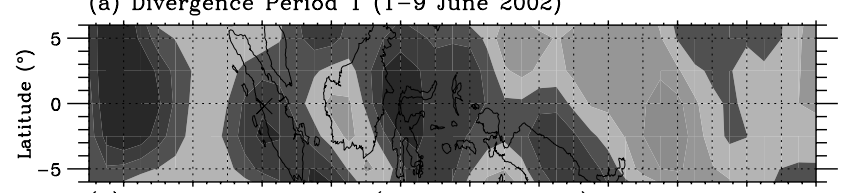

(b) Divergence Period 3 (20-26 June 2002)

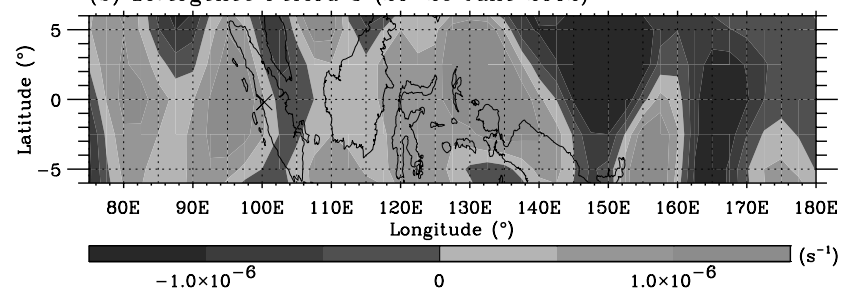

Fig. 11. Longitude-latitude plots of divergence at $1000 \mathrm{hPa}$ averaged during (a) Period 1 and (b) Period 3. Horizontal wind at $1000 \mathrm{hPa}$ are derived from NCEP/NCAR reanalysis, and bandpass filtering with cutoffs at 10 days and 60 days and $5^{\circ} \times 5^{\circ}$ running mean are applied to it.

tivities are intensified gradually over Sumatera (see Fig. 5a).

Temporal changes of surface specific humidity are affected by both large-scale convective activities (ISV and SCCs) and local-scale solar heating of the land surface. High specific humidity is observed throughout Period 1 (Fig. 10b). High solar radiation and surface temperature are simultaneously observed during Period 1 (Figs. 10c and d). This indicates that strong solar heating of the land surface induces the increase in evaporation of water from the land surface during Period 1. These conditions are favorable for the occurrence of convective events in the mountainous region of Sumatera by local circulation (Wu et al., 2003). During 11-13 June, the negative peak of solar radiation and surface temperature are observed due to the coverage of high cloud tops by CCs with $\mathrm{T}_{\mathrm{BB}}<260 \mathrm{~K}$ (see Figs. 5a, 10c, and 10d). From 13 June, surface specific humidity increases again until it reaches a positive peak on 16 June. The increase in solar radiation is also observed during 13-16 June. During 17-26 June, surface specific humidity is anomalously low, though solar radiation and surface temperature do not differ much from those observed during Period 1. It indicates that solar heating of the land surface is not the only cause for the increase in evaporation of water from the surface. As we described above, surface pressure and zonal wind are largely affected by largescale pressure and wind field caused by ISV and the Kelvinwave structure of SCCs (see Figs. 8 and 10a). Therefore, high surface pressure and low-level westerly are observed during 17-26, while low surface pressure and weak low-level zonal wind are observed during Period 1 (see Figs. 5b, 7, and 10a). It suggests that pressure and/or zonal wind affected by ISV are important factors for the enhancement (and suppression) of convective activities over Sumatera. As a mechanism for the suppression of the increase in water vapor, a penetration of dry air from the Indian Ocean to Sumatera at a low level may play an important role (Murata et al., private communication). Wu et al. (2003) suggested that local 
Table 2. Daily rainfall amount at the radar site classified by K index during November 2001.

\begin{tabular}{ccc}
\hline classification & number of days & rainfall amount \\
\hline $\mathrm{K}$ index $\leq 30$ & 4 & $3.4 \mathrm{~mm} \mathrm{day}^{-1}$ \\
$30<\mathrm{K}$ index $\leq 33$ & 10 & $5.6 \mathrm{~mm} \mathrm{day}^{-1}$ \\
$33<\mathrm{K}$ index $\leq 36$ & 11 & $7.9 \mathrm{~mm} \mathrm{day}^{-1}$ \\
$\mathrm{~K}$ index $>36$ & 2 & $4.8 \mathrm{~mm}$ day $^{-1}$ \\
\hline
\end{tabular}

circulation plays a role in the increase of water vapor at low level. Dominance of westerlies at a low level caused by ISV may suppress local circulation.

Surface temperature during Period 3 does not differ greatly from that during Period 1 in our case study, because the amount of solar radiation during Period 1 does not differ much from that during Period 3. On the other hand, during TOGA COARE, sea surface temperature decreases during the post-westerly wind burst phase of ISV, due to the reduced incoming solar radiation, enhanced evaporation and mixing, and deposition of cold water at the ocean surface by deep convection (see Fig. 4 of Chen et al., 1996). It shows that temporal variations of surface temperature caused by ISV are different between the land and sea region.

In this section, we showed that convective activities over Sumatera are significantly modulated by the ISV during June 2002. Furthermore, we show that surface data show a good agreement with temporal changes in convective activities over Sumatera modulated by ISV. In the next section, we further investigate the convective activities over Sumatera in detail, by using observational data by EAR, BLR, and GMS.

\section{Convective activities over Sumatera in June 2002}

\subsection{Variance of vertical wind observed by EAR}

\subsubsection{Comparison with $\mathrm{K}$ index computed by radiosonde data}

As an index of convective activities, we introduce the variance of vertical wind (VVW), which is computed by using the vertical wind obtained from EAR. Vertical wind generally fluctuates within very short periods $(<10 \mathrm{~min})$. However, it would be a good indicator for the intensity of convective events throughout the whole troposphere, because its variance must be large if intense convective activities exist. We define daily VVW by a variance of vertical wind in one day. To examine the usefulness of VVW, we compare VVW and $\mathrm{K}$ index values derived from radiosonde data. $\mathrm{K}$ index is defined as follows:

$\mathrm{K}$ index $=(T(850 \mathrm{hPa})-T(500 \mathrm{hPa}))+T_{\mathrm{d}}(850 \mathrm{hPa})-$

$\left(T(700 \mathrm{hPa})-T_{\mathrm{d}}(700 \mathrm{hPa})\right)$,

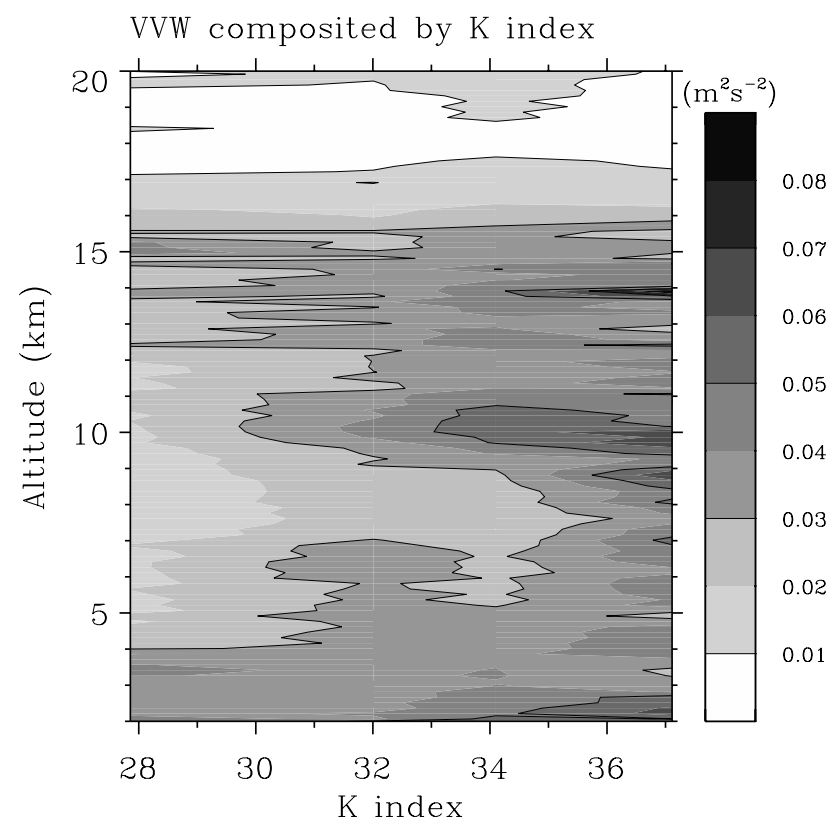

Fig. 12. Altitude profile of daily variance of vertical wind (VVW) composited by $\mathrm{K}$ index in November 2001.

where $T$ is temperature, $T_{\mathrm{d}}$ is dew point temperature, and $850 \mathrm{hPa}, 700 \mathrm{hPa}$, and $500 \mathrm{hPa}$ indicate pressure levels. A larger $\mathrm{K}$ index denotes a larger potential of convective activities (Hart and Korotky, 1991). We compute the K index from radiosonde data launched at 12:00 LT, when convective events generally begin to develop in the mountainous region of Sumatera (e.g. Mori et al., 2004; Wu et al., 2003; Renggono et al., 2001). The $\mathrm{K}$ index is an indicator of convective potential. We compare the $\mathrm{K}$ index with actual convective activities by using daily rainfall amount observed at Kototabang GAW station. Daily rainfall amount is classified by the $\mathrm{K}$ index. The result is shown in Table 2. With the increase in the $\mathrm{K}$ index, the daily rainfall amount also increases, except for one case when $\mathrm{K}$ index $>36$. Considering that the daily rainfall amount when theK index $>36$ is computed using very few samples ( 2 days), $K$ index can also be used as an indicator of the intensity for actual convective activities.

Figure 12 shows the altitude profile of daily VVW composited by the $\mathrm{K}$ index in November 2001. Throughout the troposphere, daily VVW becomes larger with the increase in the $\mathrm{K}$ index. Large daily VVW appears at $<3 \mathrm{~km}$, $\sim 10 \mathrm{~km}$, and $\sim 14 \mathrm{~km}$ altitude. Large daily VVW at $<3 \mathrm{~km}$ is caused by both moist convective activities and the planetary boundary layer turbulence resulting from buoyancy overturning. Large daily VVW at $\sim 10 \mathrm{~km}$ and $\sim 14 \mathrm{~km}$ altitudes maybe correspond to turbulence at cloud tops and the enhanced turbulence just below the tropopause altitude, respectively. Daily VVW is always weak (almost zero) above the tropopause altitude $(\sim 16-20 \mathrm{~km})$, because convective activities are weakened or stopped at the tropopause. These results show the usefulness of daily VVW as an index for the strength of convective activities in the troposphere. 


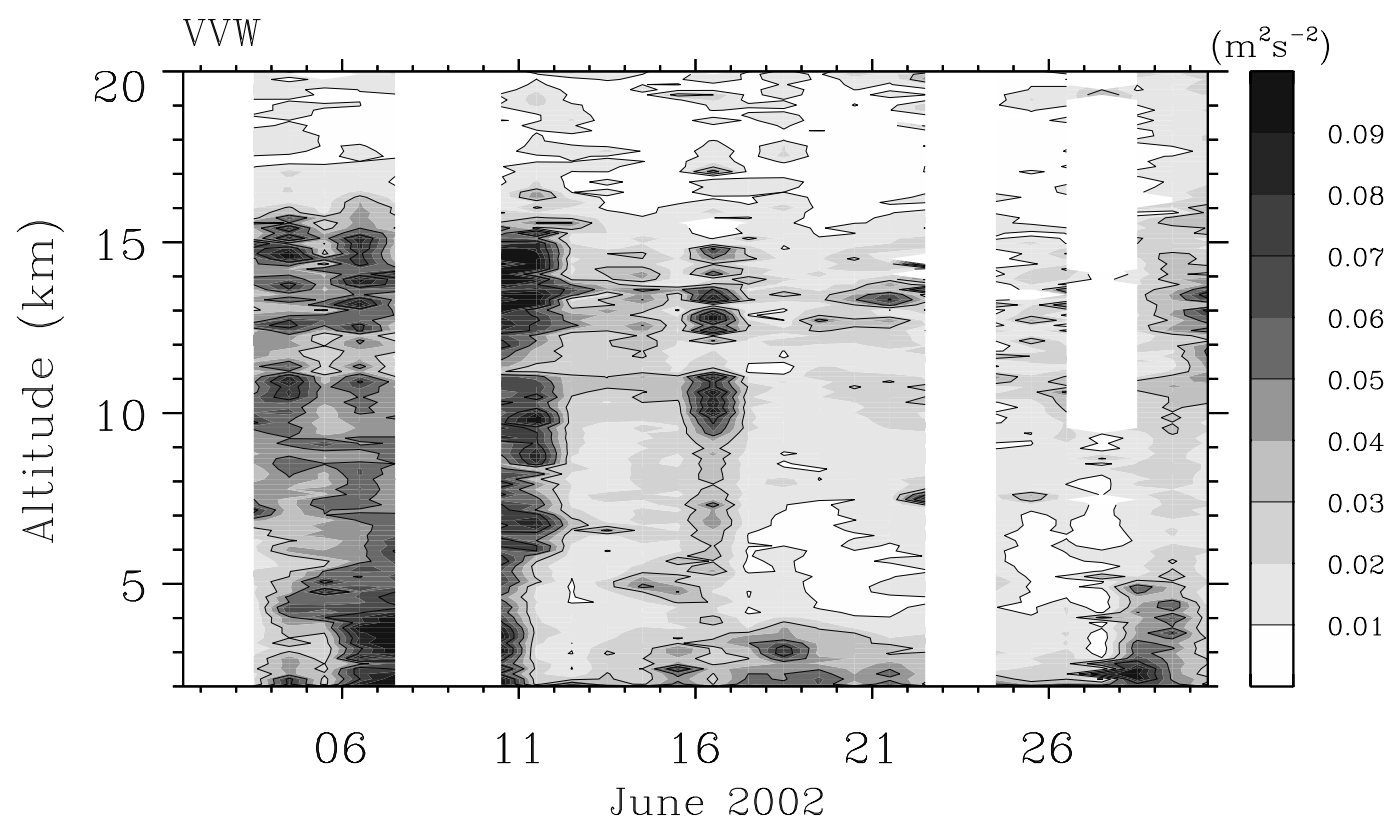

Fig. 13. Time-altitude plot of daily variance of vertical wind observed by EAR in June 2002 .

\subsubsection{Time and altitude variations of VVW in June 2002}

Figure 13 shows the time-altitude plot of daily VVW in June 2002. During Period 1 (1-9 June), VVW is large $\left(>0.05 \mathrm{~m}^{2} \mathrm{~s}^{-2}\right)$ throughout the troposphere $(2-16 \mathrm{~km}$ altitudes). On 11 June, when $\mathrm{CCs}$ with minimum $\mathrm{T}_{\mathrm{BB}}$ of $\sim 219 \mathrm{~K}(\sim 12.5 \mathrm{~km})$ covered Sumatera throughout a day (see Figs. 3 and 17), large VVW of $>0.05 \mathrm{~m}^{2} \mathrm{~s}^{-2}$ is confined only in the upper part of the troposphere (6-16 km altitudes). On 16 June, when convective activities over Sumatera are enhanced with the arrival of SCC2 (see Figs. 3 and 5a), relatively large VVW $\left(>0.03 \mathrm{~m}^{2} \mathrm{~s}^{-2}\right)$ is observed throughout almost all of the whole troposphere. Throughout Period 3, relatively large VVW $\left(>0.03 \mathrm{~m}^{2} \mathrm{~s}^{-2}\right)$ is observed at $2-4 \mathrm{~km}$ altitudes. However, VVW is small $\left(<0.01 \mathrm{~m}^{2} \mathrm{~s}^{-2}\right)$ at $4-7 \mathrm{~km}$ altitudes. This shows that convective activities do not reach above $\sim 4 \mathrm{~km}$. This result is consistent with no rainfall event over the observation site (see Fig. 9) and low cloud tops $\left(\mathrm{T}_{\mathrm{BB}}>270 \mathrm{~K}\right.$ or $\sim 5.4 \mathrm{~km}$ ) over Sumatera (see Figs. 5a).

In the next subsection, we classify precipitating clouds by using BLR data and compare them with time and altitude variations of VVW presented in this subsection.

\subsection{Classification of precipitating clouds by BLR}

To investigate the rainfall type over the observation site, classification of precipitating clouds is performed by using BLR data. The 1-min averaged reflectivity, Doppler velocity, and spectral width derived from the vertically-pointing beam are used to determine the precipitating cloud type. For the classification of precipitating clouds, we used the same algorithm used by Renggono et al. (2001). Precipitating clouds are classified into four types (stratiform, mixed stratiform/convective, deep convective, shallow convective). In the algorithm for classification, both the existence of the melting layer and the existence of enhanced turbulence above the melting level are examined (see Fig. 4 of Williams et al., 1995). If a melting layer exists and a enhanced turbulence exists (does not exist) above the melting level, a precipitating cloud is classified into mixed stratiform/convective (stratiform) type. If a melting layer does not exist and a enhanced turbulence exists (does not exist) above the melting level, a precipitating cloud is classified into deep (shallow) convective type. This classification denotes the internal structure of precipitating clouds, and does not denote the height at which convective activities can reach as denoted by $\mathrm{T}_{\mathrm{BB}}$.

Figure 14 shows the time variation of precipitating cloud types during June 2002. During Period 1, precipitating clouds are dominated by deep convective type. Large VVW $\left(>0.05 \mathrm{~m}^{2} \mathrm{~s}^{-2}\right)$ is observed throughout the troposphere during the same period (see Fig. 13). During Period 1, both observational results shown by EAR and BLR indicate the dominance of deep convections over the observation site. During Period 2, both convective-type and stratiform-type precipitating clouds are observed over the observation site. On 11 June, when high cloud tops of well-developed CC covered the radar site throughout a day, precipitating clouds are dominated by stratiform type. Large VVW $\left(>0.05 \mathrm{~m}^{2} \mathrm{~s}^{-2}\right)$ is confined in the upper part of the troposphere $(6-16 \mathrm{~km}$ altitude). Both observational results by EAR and by BLR suggest the existence of stratiform rainfall events over the observation site. During 14-15 June, precipitating clouds are dominated by the shallow convective type, and moderate VVW $\left(0.02-0.03 \mathrm{~m}^{2} \mathrm{~s}^{-2}\right)$ prevails in the whole troposphere during 14-15 June. On 16 June, when convective activities over 
Sumatera are enhanced with the arrival of SCC2 (see Figs. 3 and 5a), precipitation clouds are almost equally dominated by both shallow and deep convective cloud types. Comparatively large VVW $\left(>0.03 \mathrm{~m}^{2} \mathrm{~s}^{-2}\right)$ is observed throughout almost all of the whole troposphere over the observational site on 16 June.

As we described above, temporal variations of the precipitating-cloud type classified by BLR agree well with those of VVW. During low surface pressure, high surface specific humidity, and weak zonal wind are observed (Period 1), convective rainfall events are dominant over the observational site. During SCCs' pass over the Sumatera (Period 2), both of convective and stratiform rainfall events are observed over the observational site. In the next subsection, we discuss the difference between convective activities during Periods 1 and 2 by using $\mathrm{T}_{\mathrm{BB}}$ data observed by GMS.

\subsection{Features of convective activities observed by GMS}

Observational results by EAR and BLR indicate the dominance of deep convective events during Period 1. Hereafter we show the time evolution of cloud coverage on 2 June when deep convective events occurred over the radar site (see Fig. 14). Figure 15 shows the longitude-latitude plot of $T_{B B}$ at 16:00-23:00 LT and the hourly rainfall amount on 2 June 2002. Rainfall is observed at 18:00 LT and 20:00-21:00 LT with very high intensity at 20:00-21:00 LT $\left(>30 \mathrm{~mm} \mathrm{~h}^{-1}\right)$. Daily rainfall amount is $73 \mathrm{~mm}$. Heavy rain during 20:0021:00 LT fell from low cloud tops $\left(\mathrm{T}_{\mathrm{BB}} \sim 270 \mathrm{~K}\right)$ over the radar site. The convection center then propagates westward, and high cloud tops $\left(\mathrm{T}_{\mathrm{BB}}<220 \mathrm{~K}\right)$ are observed around $99^{\circ} \mathrm{E}$ at 23:00 LT.

The migration of cloud tops from the land to sea region is prominent through Period 1. Figure 16 shows longitudelatitude plots of diurnal variation of $\mathrm{T}_{\mathrm{BB}}$ during Period 1. At 18:00 LT, the convective region with cloud tops of $<265 \mathrm{~K}$ is observed in the mountainous region of Sumatera. The convective region migrates to the coastal region at 21:00 LT, then further migrates westward (into the sea region) until 09:00 LT. In the east coastal region of Sumatera, enhancement of the convective region with cloud tops of $<270 \mathrm{~K}$ is observed at 15:00 LT. The convective region in the east coastal region moves westward to the land region at 18:00 LT, then seems to merge with the convective regions observed in the west coastal region at 21:00 LT. Diurnal variations of convective activities are also prominent in the west coast area of Borneo.

We conclude that convective activities over Sumatera during Period 1 are mainly caused by local circulation for three reasons explained below. First, many studies have shown that convective events caused by local circulation show a migration of cloud tops from the land region to the sea region in the west side of Sumatera (e.g. Mori et al., 2004; Nitta and Sekine, 1994). In their studies, the area with high-cloud coverage appears in the coastal region in the afternoon and early night. Then it migrates to the sea region in the midnight and in the morning. Their results are consistent with our result

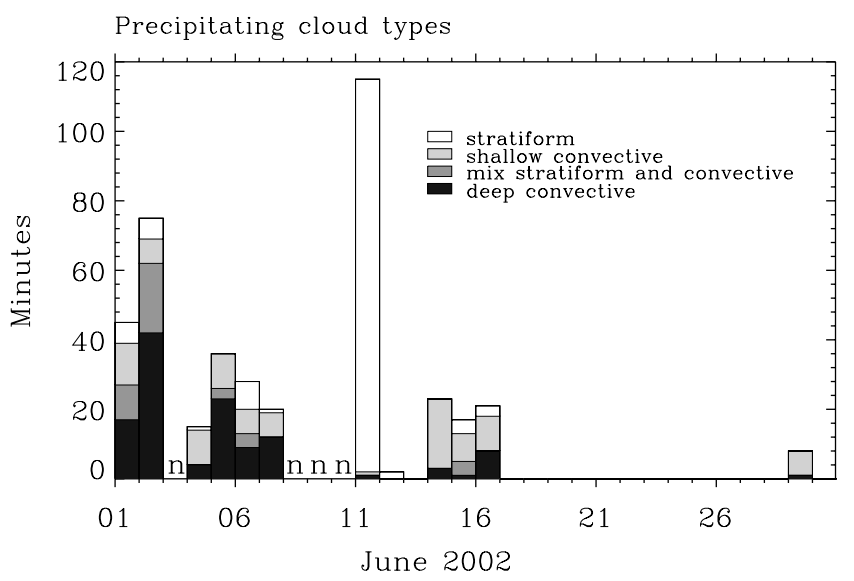

Fig. 14. Time variation of precipitating cloud types classified by BLR in June 2002. " $n$ " at the bottom indicates no data through one day.

shown in Fig. 16. Second, Wu et al. (2003) suggested that evaporation of water from the land surface by strong solar heating and horizontal transport of water vapor by thermally induced local circulation play an important role on diurnal variations of convective activities over the mountainous region of Sumatera. High specific humidity and solar radiation are observed during Period 1 (see Figs. 10b and c). It indicates that favorable conditions for the enhancement of convective activities by local circulation exist over the mountainous region of Sumatera. Third, Murata et al. (2002) suggested that convective activities caused by local circulation tend to occur when low-level zonal wind is weak. The occurrence of local circulation in the weak zonal wind at $850 \mathrm{hPa}$ is consistent with their result (see Fig. 5b). As we discussed in the previous subsection, radar observations show the dominance of deep convective events over the observation site which exists in the mountainous region of Sumatera during Period 1. EAR and BLR mainly observe vertically intense convective clouds which are induced by local circulations and exist in the mountainous area of Sumatera. Rainfall events occur with a high intensity and in a short period when convective events caused by local circulations develop over the mountainous region of Sumatera.

During Periods 2 and 3, diurnal variations of convective activities are not observed clearly in similar plots as Fig. 16 (not shown). It shows that the development of local circulation which occurs with a diurnal cycle is modulated significantly by ISV. During TOGA COARE, isolated convective cells which repeatedly penetrate into the middle and upper troposphere and moisten the air play an important role in creating favorable conditions for the organization of largescale convective systems (Redelsperger et al., 2002; Demott and Rutledge, 1998a, b). On the other hand, results in our case study suggest that convective activities by local circulation may moisten the air in the middle and upper troposphere during the inactive phase of ISV over the maritime continent. 

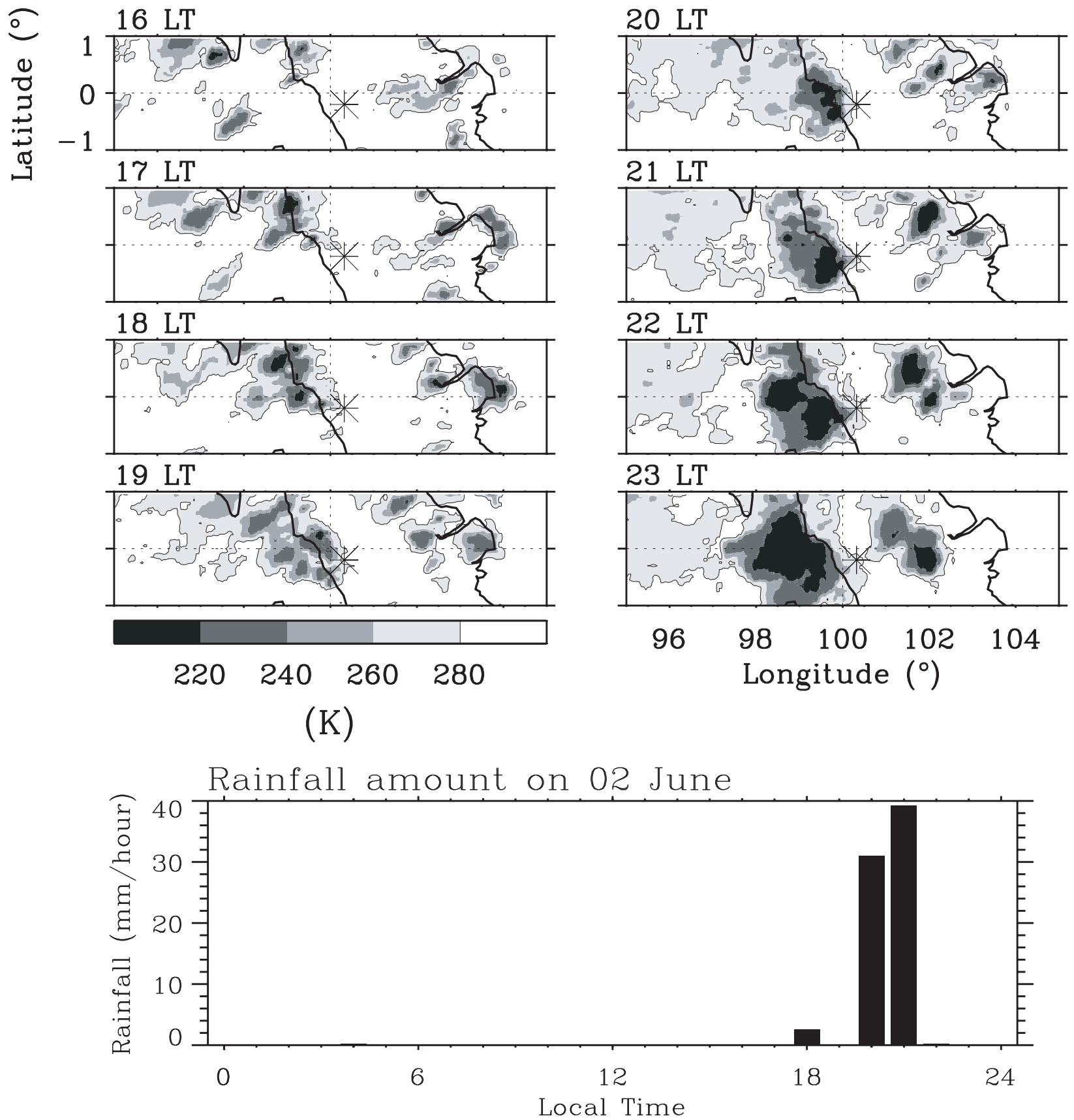

Fig. 15. Longitude-latitude plot of $\mathrm{T}_{\mathrm{BB}}$ at 16:00-23:00 LT (upper panel) and hourly rainfall (lower panel) on 2 June 2002. Spatial resolution of $\mathrm{T}_{\mathrm{BB}}$ is $0.05^{\circ} \times 0.05^{\circ}$. "*” in the upper panel indicates the location of the observation site.

This also suggests that different mechanisms may play an important role on the formation of large-scale enhanced convective activities within ISV over the open ocean (TOGA COARE) and the maritime continent (our case study). During Period 2, convective rainfall events are also observed on 14-16 June. However, cloud tops during these convective events do not show a similar migration from the land to sea region (not shown). Some processes other than local circulation may play a role in the formation of these convective rainfall events.
A stratiform rainfall event is observed on 11 June. Figure 17 is the similar plot as Fig. 15 on 11 June 2002. High cloud tops with $\mathrm{T}_{\mathrm{BB}}<215 \mathrm{~K}$ develop around $108^{\circ} \mathrm{E}$ at 01:0003:00 LT, propagate westward, and reach the east coast of Sumatera at 10:00 LT. High cloud tops pass over Sumatera around 22:00 LT. Rainfall occurs at 01:00 LT, 03:00 LT, and continuously from 12:00 LT to 23:00 LT. Rainfall events are mainly observed when high cloud tops pass over the observation site (12:00-23:00 LT). The rainfall rate is small $\left(<3.5 \mathrm{~mm} \mathrm{~h}^{-1}\right)$, the duration of rainfall is long $(\sim 11 \mathrm{~h})$, and 


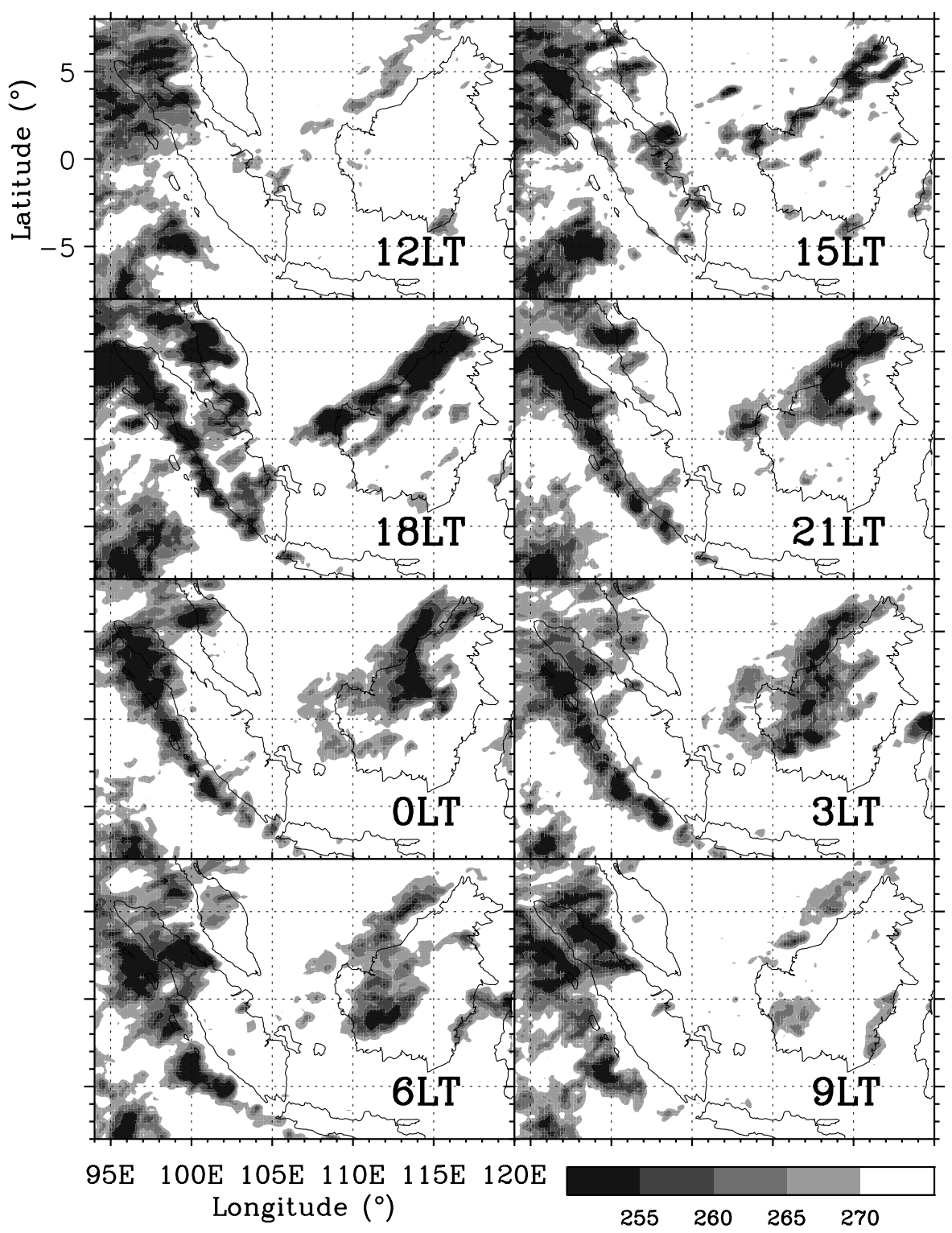

(K)

Fig. 16. Longitude-latitude plots of $\mathrm{T}_{\mathrm{BB}}$ averaged at 00:00, 03:00, 06:00, 09:00, 12:00, 15:00, 18:00 and 21:00 LT during Period 1 (1-9 June).

daily rainfall amount is large $(18 \mathrm{~mm})$. The rainfall event on 11 June shows that the well-developed CC which exists over Sumatera causes stratiform rainfall events with a small rainfall rate, a long rainfall duration, and a large rain amount.

\section{Discussion and conclusion}

In this study, we focused on the ISV event in June 2002. In June 2002, the envelope of enhanced convective activities developed over the Indian Ocean $\left(70-90^{\circ} \mathrm{E}\right)$ in the first half of June 2002, and propagated eastward from the Indian Ocean to the western Pacific. Enhanced convective activities developed over the western Pacific $\left(130-160^{\circ} \mathrm{E}\right)$ in the latter half of June 2002. Zonal wind and surface pressure at the observation site suggested the existence of Kelvin-wave-like structure of ISV.

We classified observation periods into the inactive phase, active phase, and postwesterly wind burst phase of ISV, then investigated convective features over Sumatera in different phases of ISV. During the inactive phase of ISV, convective activities over Sumatera were caused by local circulation. From radar observations, it was shown that deep convective rainfall events were dominant in the mountainous area of Sumatera. During the active and postwesterly wind burst phases of ISV, convective activities caused by local circulation were 

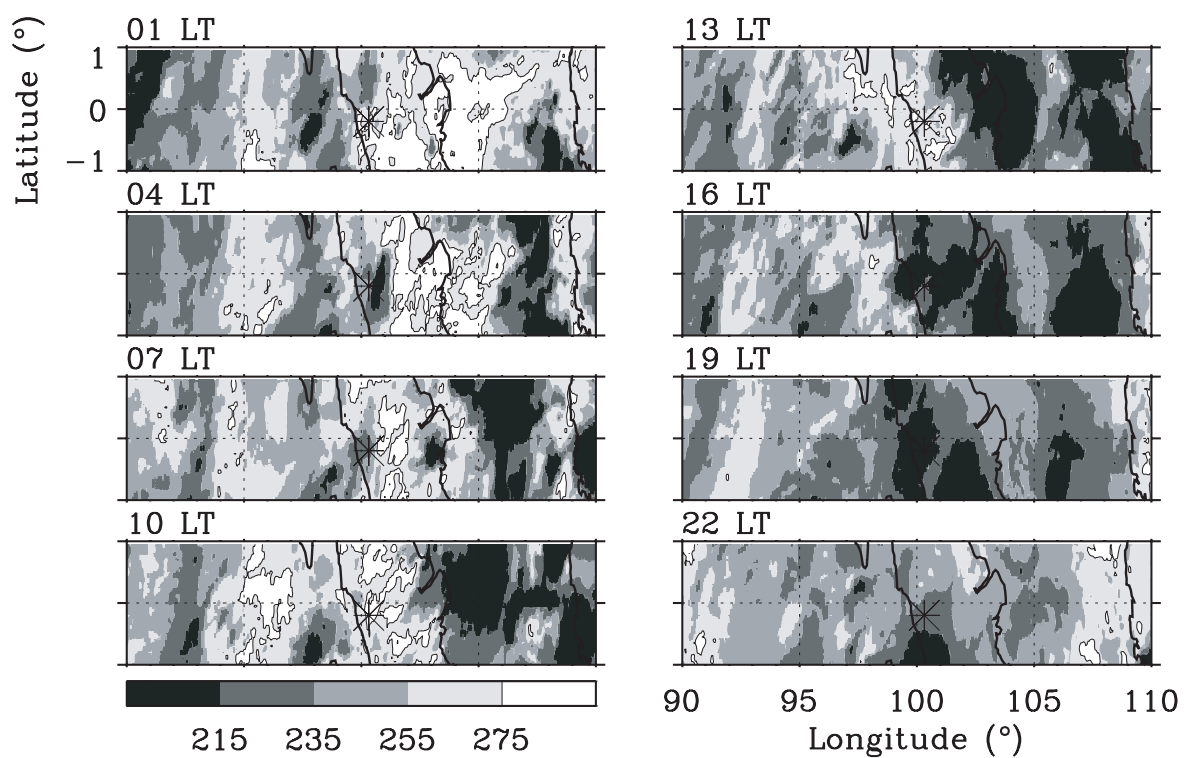

(K)

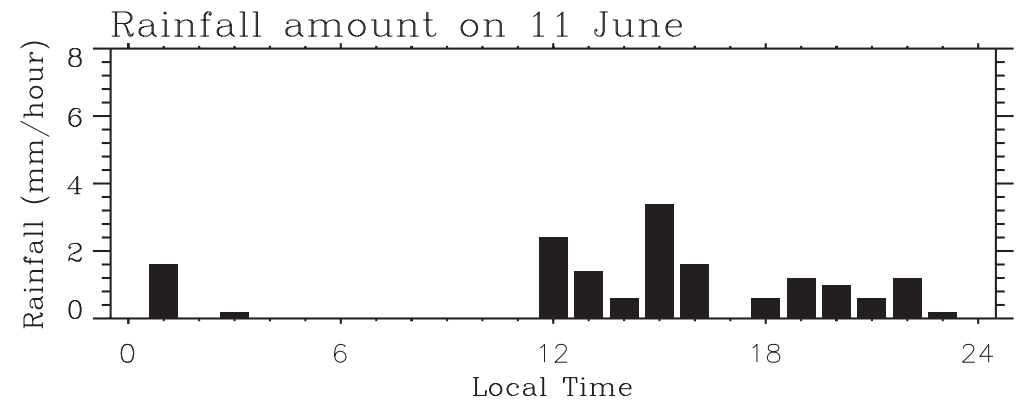

Fig. 17. Same as Fig. 15 except for 11 June 2002, and that $T_{B B}$ is shown every 3 h during 01:00-22:00 LT and the range of vertical axis in the lower panel is $0-8 \mathrm{~mm} \mathrm{~h}^{-1}$.

not prominent over Sumatera. It shows that convective activities caused by local circulation are controlled by ISV. Convective activities caused by local circulation may play an important role in the moistening of the middle and upper troposphere in the inactive phase of ISV. Two SCCs passed over Sumatera in the active phase of ISV, and both convective and stratiform rainfall events were observed over the observation site. CCs which developed in the convectively active envelope of SCC1 passed over Sumatera and caused rainfall events over the observation site. Especially on 11 June, a well-developed CC passed over Sumatera, and resulted in a long-lived stratiform rainfall event. With the passage of SCC2 over Sumatera, shallow and deep convective rainfall events were observed over the observation site. In SCC2, formation of CC was not observed over Sumatera. However, formation of CCs within SCC2 were observed over the western Pacific. During the postwesterly wind burst phase of ISV, convective activities were suppressed over Sumatera.

Convective features over Sumatera observed during June 2002 were generally consistent with those observed during TOGA COARE. However, it was suggested that the enhancement of convective activities caused by local circulation may play an important role in the moistening of the middle and upper troposphere over Sumatera. Saxen and Rutledge (2000) compared GPI, radar-derived rainfall rate, and vertical wind shear and showed that rainfall rate is largely dependent on changes in the tropospheric vertical shear of horizontal wind modulated by ISVs. Well-organized mesoscale convective systems with a spatial scale of $>100 \mathrm{~km}$ are more frequently organized under the condition of larger vertical wind shear, and the slope coefficient used in GPI decreases with the increase in vertical wind shear due to the increase in stratiform clouds in a well-organized mesoscale convective system. However, our observations cannot show a spatial scale of mesoscale convective systems over Sumatera, because our radar observations were limited to one point (i.e. observation site). As we mentioned in Sects. 3 and 4, enhanced convection was not observed in the postwesterly wind burst phase of ISV. Further studies of different ISV cases are necessary to clarify whether or not this is a characteristic feature over Sumatera. In April and May 2004, our research group carried out the simultaneous observation campaign 
with meteorological radars, radiosondes, BLR, and EAR. We will show further detailed features of convective activities over Sumatera and their relation to ISV through this observation campaign.

The ISV which we focused on occurred during the dry season. The rainy season of the equatorial region of Sumatera is boreal spring (from March to May) and fall (from September to November) seasons (Hamada et al., 2002). The influence of ISV on convective activities over Sumatera may significantly change between dry and rainy seasons. For example, the enhanced convective activities (with daily $\mathrm{T}_{\mathrm{BB}}<260 \mathrm{~K}$ ) are observed over the Indian Ocean even in the inactive phase ISV from 10 to 31 October (see Fig. 2) in the rainy season. Chen and Houze (1997) show that interannual variations of deep convection in the Indian Ocean are induced by El Niño/Southern Oscillation (ENSO). Investigations of other ISV cases are necessary to clarify annual and interannual variations of the ISV's influence on convective activities over Sumatera. Model simulations to investigate the relationship between convective activities by local circulation and ISV will describe the detailed behavior of ISVs over the maritime continent.

There are still many factors other than ISV that influence convective activities over Sumatera. Murata et al. (2002) focused on the case during the rainy season (SeptemberOctober 1998) and showed that precipitation events are frequently observed in the mountainous area of Sumatera during the weak westerly phase of quasi-10-day variations of lowlevel $(1-3 \mathrm{~km})$ zonal wind. It indicates that convective activities by local circulation are controlled by some factors with a shorter time scale than ISV. The relation between convection by local circulation and gravity waves must be clarified in the future. We hope that this study helps to understand the ISVs' behavior over the maritime continent. Further observational studies of ISVs' behavior near Sumatera is now in progress, and will be shown in subsequent papers.

Acknowledgements. The authors thank M. Fujiwara of Environmental Earth Science of Hokkaido University, Japan and T. Horinouchi of Research Institute for Sustainable Humanosphere (RISH) of Kyoto University, Japan for their valuable comments and suggestions. They thank F. Tsujino for helping data analysis, and G. Hassenpflug for careful reading of the manuscript. Two anonymous reviewers, who offered many valuable comments, are greatly acknowledged. They also wish to thank Frontier Observation Research System for Global Change (FORSGC), Japan, the Indonesian Agency for the Assessment and Application of Technology (BPPT), Indonesia, and the Indonesian Meteorological and Geophysical Agency (BMG), Indonesia, for providing radiosonde data. GMS blackbody brightness temperature data were observed by Japan Meteorological Agency (JMA), and distributed by Kochi University, Japan. NCEP/NCAR reanalysis data sets were provided from the anonymous ftp sites of the National Ocean and Atmospheric Administration/Climate Diagnostic Center. EAR belongs to RISH and is operated by RISH and National Institute of Aeronautics and Space (LAPAN), Indonesia based upon the agreement between RISC and LAPAN signed on 8 September 2000. They also thank operators who maintain EAR and BLR. The present study was partially supported by Grant-in-Aid for Scientific Research on Priority
Area-764 of the Ministry of Education, Culture, Sports, Science, and Technology (MEXT) of Japan. The first author was financially supported by Loan Japan Bank for International Cooperation (JBIC) - Science, Technology, and Industrial Development (STAID) Program of Indonesian government. He is supported by Japan Society for the Promotion of Science (JSPS) RONPAKU (Dissertation Ph.D.) Program.

Topical Editor U.-P. Hoppe thanks two referees for their help in evaluating this paper.

\section{References}

Carter, D. A., Gage, K. S., Ecklund, W. L., Angevine, W. M., Johnston, P. E., Riddle, A. C., Wilson, J., and Williams, C. R.: Developments in UHF lower tropospheric wind profiling at NOAA's Aeronomy Laboratory, Radio Sci., 30, 977-1001, 1995.

hen, S. S., Houze, R. A., and Mapes, B. E.: Multiscale variability of deep convection in relation to large-scale circulation in TOGA COARE, J. Atmos. Sci., 53, 1380-1409, 1996.

Chen, S. S. and Houze, R. A.: Interannual variability of deep convection over the tropical warm pool, J. Geophys. Res., 102, 25 783-25 795, 1997.

DeMott, C. A. and Rutledge, S. A.: The vertical structure of TOGA COARE convection. Part I: Radar Echo Distributions, J. Atmos. Sci., 55, 2730-2747, 1998a.

DeMott, C. A. and Rutledge, S. A.: The vertical structure of TOGA COARE convection, Part II: Modulating influences and implications for diabatic heating, J. Atmos. Sci., 55, 2748-2762, 1998 b.

Dunkerton, T. J. and Crum, F. X.: Eastward propagating 2- to 15day equatorial convection and its relation to the tropical intraseasonal oscillation, J. Geophys. Res., 100, 25 781-25 790, 1995.

Fukao, S., Hashiguchi, H., Yamamoto, M., Tsuda, T., Nakamura, T., Yamamoto, M. K., Sato, T., Hagio, M., and Yabugaki, Y.: Equatorial Atmosphere Radar (EAR): System description and first results, Radio Sci., 38, 1053, doi:10.1029/2002RS002767, 2003.

Gage, K. S.: The structure and dynamics of the free atmosphere as observed by VHF/UHF radar, in Radar in Meteorology, edited by: Atlas, D., American Meteorological Society, Boston, Mass., 534-565, 1990.

Gage, K. S., Balsley, B. B., Ecklund, W. L., Carter, D. A., and McAfee, J. R.: Wind profiler-related research in the tropical Pacific, J. Geophys. Res., 96, 3209-3220, 1991.

Hamada, J., Yamanaka, M. D., Matsumoto, J., Fukao, S., Winarso, P. A., and Sribimawati, T.: Spatial and temporal variations of the rainy season over Indonesia and their link to ENSO, J. Meteor. Soc. Japan, 80, 285-310, 2002.

Hart, J. A. and Korotky, J.: The SHARP Workstation (computer program), NOAA/NWS, 1991.

Hashiguchi, H., Fukao, S., Tsuda, T., Yamanaka, M. D., Tobing, D. L., Sribimawati, T., Harijono S. W. B., and Wiryosumarto, H.: Observations of the planetary boundary layer over equatorial Indonesia with an L-band clear-air Doppler radar: Initial results, Radio Sci., 30, 1043-1053, 1995.

Hendon, H. H. and Woodberry, K.: The diurnal cycle of tropical convection, J. Geophys. Res., 98, 16623-16637, 1993.

Hendon, H. H. and Salby, M. L.: The life cycle of the MaddenJulian oscillation, J. Atmos. Sci., 51, 2225-2237, 1994.

Hendon, H. H. and Liebmann, B.: Organization of convection within the Madden-Julian oscillation, J. Geophys. Res., 99, 8073-8083, 1994. 
Larsen, M. F. and Röttger, J.: VHF and UHF Doppler radars as tool for synoptic research, Bull. Am. Meteorol. Soc., 63, 996-1008, 1982.

Lau, K. M., Peng, L., Sui, C. H., and Nakazawa, T.: Super cloud clusters, westerly wind bursts, 30-60 day oscillations and ENSO: A unified view, J. Meteor. Soc. Japan, 67, 205-219, 1989.

Lau, K. M., Nakazawa, T., and Sui, C. H.: Observations of cloud cluster hierarchies over the tropical western Pacific, J. Geophys. Res., 96, 3197-3208, 1991.

Lin, X. and Johnson, R. H.: Kinematic and thermodynamic characteristics of the flow over the western Pacific warm pool during TOGA COARE, J. Atmos. Sci., 53, 695-715, 1996.

Madden, R. A. and Julian, P. R.: Observations of the 40-50-day tropical oscillation - A review, Mon. Wea. Rev., 122, 814-837, 1994.

Madden, R. A.: Seasonal variations of the 40-50 day oscillation in the tropics, J. Atmos. Sci., 43, 3138-3158, 1986.

Matthews, A. J.: Propagation mechanisms for the Madden-Julian oscillation, Quart. J. Roy. Meteor. Soc., 126, 2637-2652, 2000.

Mori, S., Hamada, J., Tauhid Y. I., Yamanaka, M. D., Okamoto, N., Murata, F., Sakurai, N., Hashiguchi, H., and Sribimawati, T.: Diurnal land-sea rainfall peak migration over Sumatera island, Indonesian maritime continent observed by TRMM satellite and intensive rawinsonde soundings, Mon. Wea. Rev., 132, 20212039, 2004.

Murata, F., Yamanaka, M. D., Fujiwara, M., Ogino, S.-Y., Hashiguchi, H., Fukao, S., Kudsy, M., Sribimawati, T., Harijono, S. W. B., and Kelana, E.: Relationship between wind and precipitation observed with a UHF Radar, GPS rawinsondes and surface meteorological instruments at Kototabang, West Sumatera during September-October 1998, J. Meteor. Soc. Japan, 80, 347-360, 2002.

Nakazawa, T.: Tropical super clusters within intraseasonal variations over the western Pacific, J. Meteor. Soc. Japan, 66, 823839, 1988.

Nitta, Ts. and Sekine, S.: Diurnal variation of convective activity over the tropical western Pacific, J. Meteor. Soc. Japan, 72, 627641, 1994.

Nitta, Ts., Mizuno, T., and Takahashi, K.: Multi-scale convective systems during the initial phase of the 1986/1987 El Niño, J. Meteor. Soc. Japan, 70, 447-466, 1992.

Ohno, Y.: Land and sea breezes observed by a $1357 \mathrm{MHz}$ wind profiler, Proceedings of the Seventh Workshop on Technical and Scientific Aspects of MST Radar, South Carolina, 7-11 November 1995, 323-326, 1995.

Okamoto, N., Yamanaka, M. D., Ogino, S.-Y., Hashiguchi, H., Nishi, N., Sribimawati, T., and Numaguti, A.: Seasonal variations of tropospheric wind over Indonesia: Comparison between collected operational rawinsonde data and NCEP reanalysis for 1992-1999, J. Meteor. Soc. Japan, 81, 829-850, 2003.
Rao, P. B., Jain, A. R., Kishore, P., Balamuralidhar, P., Damle, S. H., and Viswanathan, G.: Indian MST radar 1. System description and sample vector wind measurements in ST mode, Radio Sci., 30, 1125-1138, 1995.

Reddy, M. C., Ghosh, A. K., Kumar, V. S., Jain, A. R., Kozu, T., and Reddy K. K.: Integrated measurements of atmospheric winds using Indian MST radar and lower atmosphere wind profiler (LAWP), Proceeding of the Ninth International Workshop on Technical and Scientific Aspects of MST Radar, Toulouse, 13-18 March 2002, 222-225, 2002.

Redelsperger, J.-L, Parsons, D. B., and Guichard, F.: Recovery processes and factors limiting cloud-top height following the arrival of a dry air intrusion observed during TOGA COARE, J. Atmos. Sci., 59, 2438-2457, 2002.

Renggono, F., Hashiguchi, H., Fukao, S., Yamanaka, M. D., Ogino, S.-Y., Okamoto, N., Murata, F., Sitorus, B. P., Kudsy, M., Kartasasmita, M., and Ibrahim, G.: Precipitating clouds observed by $1.3-\mathrm{GHz}$ boundary layer radars in equatorial Indonesia, Ann. Geophys., 19, 889-897, 2001.

Rickenbach, T. M. and Rutledge, S. A.: Convection in TOGA COARE: Horizontal scale, morphology, and rainfall production, J. Atmos. Sci., 55, 2715-2729, 1998.

Rui, H. and Wang, B.: Development characteristics and dynamic structure of tropical intraseasonal convection anomalies, J. Atmos. Sci., 47, 357-379, 1990.

Saxen, T. R. and Rutledge, S. A.: Surface rainfall-cold cloud fractional coverage relationship in TOGA COARE: A function of vertical wind shear, Mon. Wea. Rev., 128, 407-415, 2000.

Thomas, L.: Applications of the NERC MST radar facility in mesoscale studies, Meteorol. Appl., 6, 133-142, 1999.

Wang, B.: Dynamics of tropical low-frequency waves: An analysis of the moist Kelvin wave, J. Atmos. Sci., 45, 2051-2065, 1988.

Wang, B. and Rui, H.: Synoptic climatology of transient tropical intraseasonal convection anomalies: 1975-1985, Meteorol. Atmos. Phys., 44, 43-61, 1990.

Weickmann, K. M. and Khalsa, S. J. S.: The shift of convection from the Indian Ocean to the western Pacific Ocean during a 3060 day oscillation, Mon. Wea. Rev., 118, 964-978, 1990.

Widiyatmi, I., Hashiguchi, H., Fukao, S., Yamanaka, M. D., Ogino, S.-Y., Gage, K. S., Harijono, S. W. B., Diharto, S., and Djojodihardjo, H.: Examination of 3-6 day disturbances over equatorial Indonesia based on boundary layer radar observations during 1996-1999 at Bukittinggi, Serpong and Biak, J. Meteor. Soc. Japan, 79, 317-331, 2001.

Williams, C. R., Ecklund, W. L., and Gage, K. S.: Classification of precipitating clouds in the tropics using $915-\mathrm{MHz}$ wind profilers, J. Atmos. Oceanic Technol., 12, 996-1012, 1995.

Wu, P., Hamada, J., Mori, S., Tauhid, Y. I., Yamanaka, M. D., and Kimura, F.: Diurnal variation of precipitable water over a mountainous area of Sumatra island, J. Appl. Meteor., 42, 1107-1115, 2003. 